Archaeologia Historica Polona tom 25, 2017, ISSN 1425-3534

Instytut Archeologii

Uniwersytet Jagielloński

http://dx.doi.org/10.12775/AHP.2017.001

DARIUSZ NIEMIEC

\title{
Piece do wypału ceramiki budowlanej i wapna w XIII-wiecznym klasztorze Dominikanów w Krakowie
}

\section{Kilns for firing construction ceramics and limekilns in the $13^{\text {th }}$ century Dominican monastery in Cracow}

Zarys treści. W artykule opisano relikty XIII-wiecznych pieców odkrytych na terenie krakowskiego klasztoru Dominikanów, służących do produkcji cegieł i innych wysokogatunkowych wyrobów ceramicznym, między innymi kształtek ceramicznych, płytek posadzkowych, a także pieców wapienniczych. Zaprezentowano też inne aspekty XIII-wiecznego warsztatu i zaplecza budowlanego rozpoznanego w tym miejscu w wyniku badań archeologicznych. Dokonano skrótowej charakterystyki odkrytego tutaj późnoromańskiego i wczesnogotyckiego ceglanego detalu architektonicznego, w tym ornamentowanych płytek posadzkowych, zarówno gotowych wyrobów, jak i półproduktów.

Stowa kluczowe: klasztor Dominikanów, piece produkcyjne, warsztat budowlany, ceramika budowlana, późnoromańskie płytki posadzkowe.

Badania archeologiczne prowadzone w szerokiej przestrzeni wokół krakowskiego kościoła Dominikanów i na terenie samego klasztoru dostarczyły wyjątkowych odkryć związanych z funkcjonowaniem od XIII wieku rozbudowanego zaplecza budowlanego (ryc. 1), być może obsługiwanego przez ówczesnych konwersów zakonnych. W obrębie tego zaplecza zidentyfikowano liczne piece do wypału wapna i stanowisko strycharza, gdzie przed wypałem suszono gliniane półprodukty cegieł oraz kilka pieców związanych z produkcją szerokiego asortymentu ceramiki budowlanej, wreszcie liczne pojedyncze znaleziska ceramicznych pólfabrykatów oraz niedokończone elementy ceramiki budowlanej uszkodzone 
w trakcie wypałuํ. Działalność tego warsztatu ceramicznego miała podstawowe znaczenie dla pojawienia się w XIII wieku cegły w architekturze Krakowa. Bardzo wczesne obiekty, pochodzące z tego stulecia, związane z produkcją cegły, odkryto w szerokiej strefie od rejonu kamienic przy ulicy Dominikańskiej 1-3, znajdującej się na południe od kościoła Świętej Trójcy do co najmniej obszaru III wirydarza, położonego znacząco na północ od świątyni konwentualnej (ryc. 1). Zwraca uwagę skala produkcji warsztatu czytelna nie tylko pod względem terytorialno-przestrzennym, ale też w zakresie bogatego asortymentu odkrytej tu ceramiki budowlanej.

Początki tej produkcji można odnosić do lat 30. XIII wieku, gdy cegła jako nowy budulec pojawiła się po raz pierwszy w architekturze krakowskiego klasztoru Dominikanów, a konkretnie, gdy rozpoczęto tutaj wznoszenie pierwszych budowli ceglanych - krypty pod prezbiterium i skrzydła wschodniego klasztoru wraz z pierwotnym kapitularzem (Bojęś-Białasik, Niemiec 2016a, s. 249-250, ryc. 2, 3, 6; 2016b, s. 35-36, ryc. 1-3). Przekonywujących dowodów na takie ich datowanie dostarczyły badania archeologiczne prowadzone w krakowskim klasztorze Dominikanów w latach 2009-2014, a zwłaszcza odkrycia dokonane w obrębie warstw zgliszcz łączonych ze skutkami i najazdu mongolskiego z 1241 roku, w których wraz z grocikami mongolskimi znaleziono stosunkowo liczne fragmenty przepalonych i miejscami zżużlonych cegieł². Analogie do nich można wskazać jedynie wśród pozostałości późnoromańskiej fazy budownictwa, rozpoznanego w krypcie pod prezbiterium kościoła ${ }^{3}$ oraz w reliktach najstarszej fazy wschodniego skrzydła klasztoru, odkrytymi w murach identyfikowanych z pozostałościami najstarszego kapitularza ${ }^{4}$ (Bojęś-Białasik, Niemiec 2012, s. 258-272, 298-300, 306; Bojęś-Białasik, Niemiec 2016c, s. 494). Na licach cegieł związanych z tym najstarszym horyzontem ceglanej zabudowy krakowskiego klasztoru widoczne są wyraźne i intencjonalnie wykonane nacięcia o ukośnym układzie linii równoległych lub w jodełkę. W Małopolsce podobne formaty cegieł $(7-8,5 \times 12-13,5 \times 26-27 \mathrm{~cm})$ stwierdzono jedynie w kościele i klasztorze Dominikanów w Sandomierzu. Dla tych najstarszych egzemplarzy z klasztorów dominikańskich w Krakowie i Sandomierzu można wskazać odpowiedniki wśród cegieł użytych w 1. połowie XIII wieku do budowy dormitorium i refektarza klasztoru Dominikanów w Bolonii ${ }^{5}$. Warto przy tym zwrócić uwagę, że rozmiary, a zwłaszcza wysokość cegieł produkowanych w bolońskim klasztorze znacznie

\footnotetext{
${ }^{1}$ Prezentowane w artykule piece pochodzą z badań archeologicznych prowadzonych przez Instytut Archeologii Uniwersytetu Jagiellońskiego w latach 2009-2014, pod kierunkiem Dariusza Niemca oraz badań Andrzeja Żakiego z 1962 roku i Moniki Łyczak z 2011 roku.

${ }^{2}$ Wymiary główek tych cegieł 7,5-8×12 cm, $8 \times 10 \mathrm{~cm}$ i $8 \times 14 \mathrm{~cm}$.

${ }^{3}$ Wymiary cegiel: 7,5-8×11-12,5×25-26 cm.

${ }^{4}$ Wymiary cegieł: 7,5-8×12,5×25,5-27 cm.

${ }^{5}$ Mury tej części klasztoru wzniesiono z cegieł o wymiarach 7-8,5×11-13,5×27-29,5 cm (Brunetti, Carlo, Basso 1987, s. 226-227).
} 


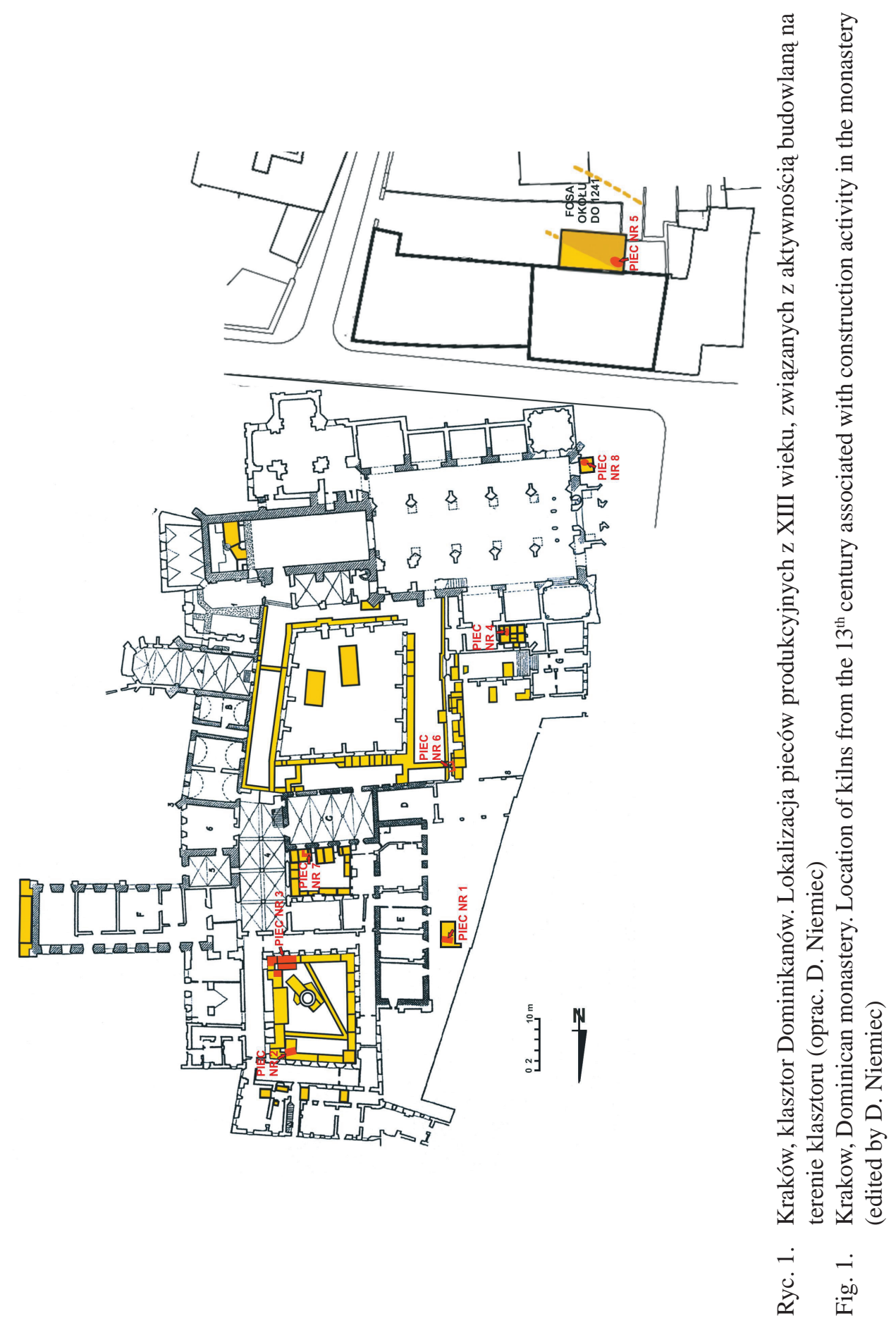


odbiegała od ówczesnych typowych cegieł $(5 \times 12,6 \times 28,5 \mathrm{~cm})$ produkowanych przez miejskie cegielnie w Bolonii (Brunetti, Carlo, Basso 1987, s. 226).

Wspomniane najstarsze elementy murowanej zabudowy dominikańskiej z Krakowa są jednocześnie najstarszymi zabytkami ceglanej architektury w Małopolsce, zaś przedstawicieli zakonu kaznodziejskiego uznać należy za pionierów i promotorów produkcji i zastosowania tego materiału budowlanego w tym regionie, czego dobitnie dowodzą relikty jego późnoromańskiego ceglanego założenia klasztornego odkryte w Krakowie (Kopera 1926, s. 66-68, ryc. 27-29; Szyma 2004, s. 45-46, 52-53, 87, 107-109, ryc. 32, 34-36, 56, 120, 124, 125; Bojęś-Białasik, Niemiec 2016a, s. 249-250, ryc. 2, 3, 6; Bojęś-Białasik, Niemiec 2016b, s. 35-36, ryc. 1-3; 2016c, s. 494) oraz równie wczesne zabudowania klasztorne zachowane w Sandomierzu (Gołubiew 1975; Florek 1993, s. 111-138; 1994, s. 3-25). Część badaczy z oddziaływaniami warsztatów dominikańskich wiąże też genezę i najstarszą architekturę ceglaną w państwie zakonu krzyżackiego (Frycz 1978, s. 35-37; Arszyński 2016, s. 36-38 - tam starsza literatura; por. też Niemiec 2016, s. 206).

W 2014 roku, w krakowskim klasztorze Dominikanów, w obrębie południowej części tzw. II wirydarza i bezpośrednim styku kamiennych i ceglanych fundamentów romańskiego refektarza odkryto relikty pieca do wypału ceramiki budowlanej - dachówek i płytek posadzkowych (piec nr 7; ryc. 1, 2). Obiekt ten może być rekonstruowany jako co najmniej dwukondygnacyjna konstrukcja służącą do wypału wapna i ceramiki budowlanej. Najlepiej zachowaną dolną kondygnacją pieca była ściana północna komory paleniskowej, wkopana w calcowe podłoże. Tę najniżej położoną ścianę o grubości $80 \mathrm{~cm}$ wykonano z cegieł o wymiarach $8,5 \times 13 \times 27,5 \mathrm{~cm}, 9 \times 13 \times 27,5 \mathrm{~cm}$ i $9,5 \times 14 \times 28 \mathrm{~cm}$, spojonych szarą gliną, bez użycia zaprawy. Otwór wlotowy do komory paleniskowej znajdował się mniej więcej na linii lica południowego gotyckiej przypory refektarza. Szerokość zachowanej do tego miejsca całej połówki ściany pieca wynosiła $250 \mathrm{~cm}$, zatem na tej podstawie można oceniać, że cała ściana czołowa musiała mieć szerokość 500-550 cm. Rejon otworu wlotowego do pieca został naruszony i zniszczony przez narożnik sklepionej ceglanej piwniczki późnoromańskiej, dobudowanej wtórnie do refektarza, odkrytej pomiędzy jego przyporami. Z reliktami drugiej połówki ściany czołowej pieca można łączyć niewielki fragment muru ceglanego, spojonego glina, odsłoniętego pomiędzy przyporami refektarza. Z elementami zniszczonej drugiej kondygnacji pieca (ścianki działowej w komorze paleniskowej?) być może związany był przemieszczony fragment muru ceglanego, spojonego zaprawą wapienną, odkryty nieco wyżej od zachowanych in situ elementów pieca. W obrębie warstw związanych z budową refektarza nie zachowały się pozostałe mury obwodowe pieca, a zwłaszcza żaden relikt ściany południowej, co wyraźnie dowodzi, że piec musiał funkcjonować zanim jeszcze rozpoczęto wznoszenie najniższych partii refektarza. Również pośrednio wskazuje 


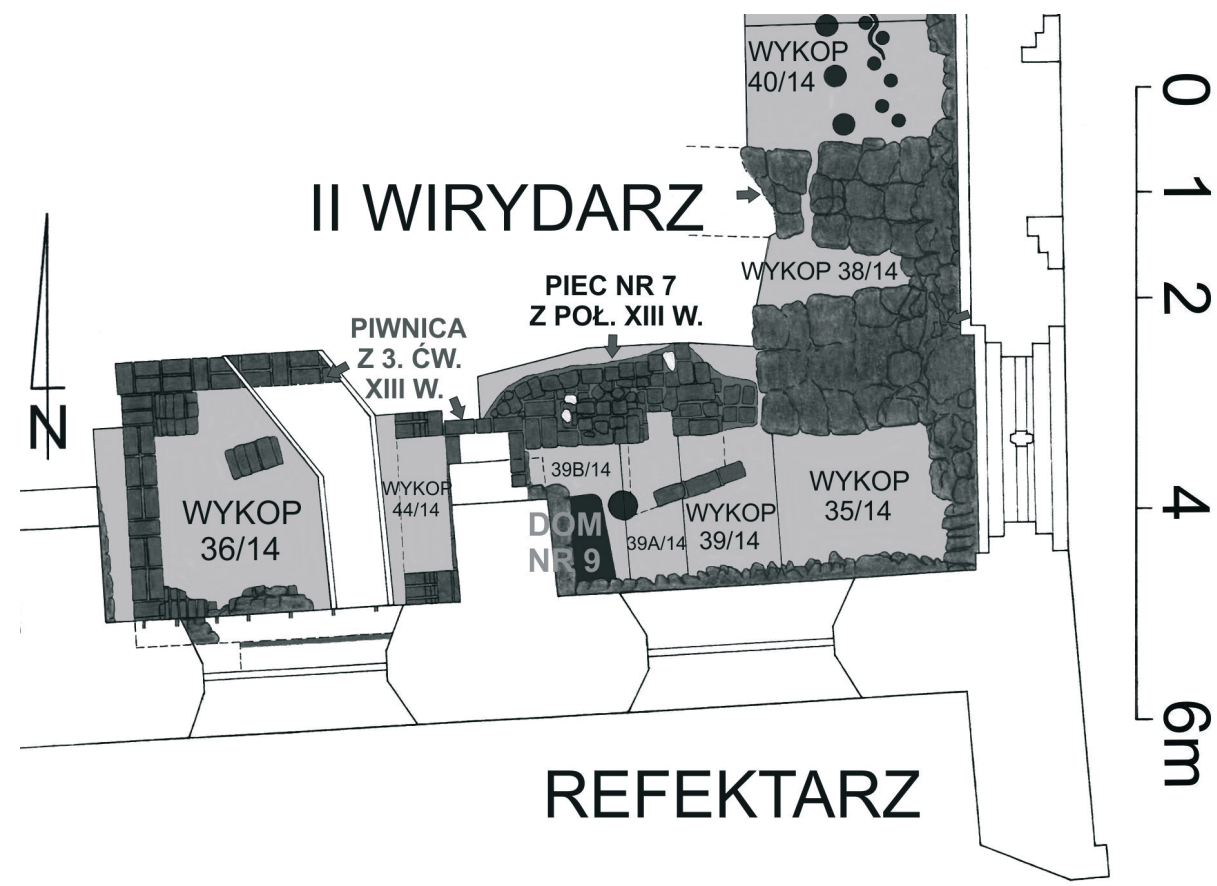

Ryc. 2. Kraków, klasztor Dominikanów. Plan z reliktami pieca nr 7 z połowy XIII wieku, odkrytymi w południowej części II wirydarza (oprac. D. Niemiec)

Fig. 2. Krakow, Dominican monastery. Plan with the remains of kiln No. 7 from the mid- $13^{\text {th }}$ century, discovered in the southern part of the cloister garth II (edited by D. Niemiec)

na to ukośna orientacja rzutu z zachowanymi murami pieca w stosunku do ściany północnej refektarza. Wśród pozostałości komory paleniskowej natrafiono na duże fragmenty potłuczonej i świeżo wypalonej dachówki typu mnich-mniszka oraz jeden niewielki fragment późnoromańskiej płytki posadzkowej z doskonale zachowanym reliefem, bez śladów zużycia, z wyobrażeniem ręki trzymającej miecz (ryc. 3). Ostatecznie stwierdzić należy, ze opisany piec został zniszczony w początkowej fazie budowy fundamentów i ścian cellarium romańskiego refektarza. W świetle aktualnej wiedzy o początkach architektury ceglanej w krakowskim klasztorze Dominikanów budowę i użytkowanie tego pieca łączyć należy z początkiem lat 40. XIII wieku i wykończeniem (częściową odbudową po najeździe mongolskim w 1241 roku?) najstarszych ceglanych zabudowań klasztornych, czyli wykonaniem zadaszeń i posadzek skrzydła wschodniego z kapitularzem ${ }^{6}$ oraz być może zadaszenia nad nowo budowanym ceglanym prezbiterium kościoła, jak i pierwotnym dominikańskim kościołem kamiennym

\footnotetext{
${ }^{6}$ Najprawdopodobniej przed 1244 rokiem jak sugeruje to najwcześniejsza wzmianka o funkcjonowaniu kapitularza.
} 


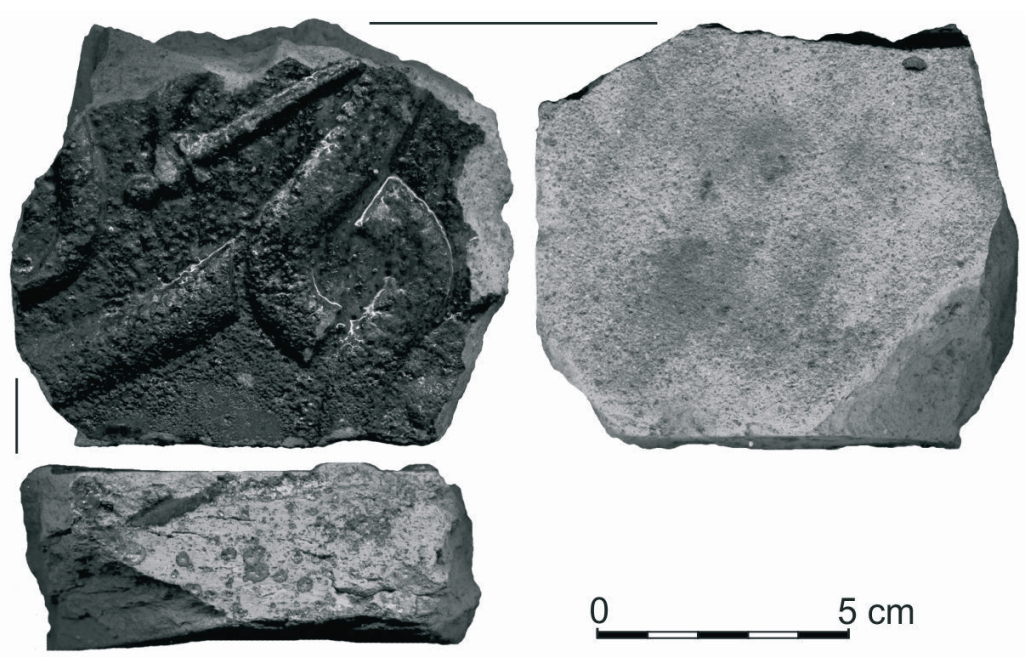

Ryc. 3. Kraków, klasztor Dominikanów. Fragment późnoromańskiej płytki posadzkowej z wyobrażeniem ręki trzymającej miecz (bez śladów zużycia powierzchni użytkowej), odkryty w obrębie rozwaliska pieca nr 2 na II wirydarzu (oprac. U. Bąk)

Fig. 3. Krakow, Dominican monastery. Fragment of a late Romanesque floor tile with the representation of a sword-holding hand (no traces of wear of the usable surface), discovered within the kiln No. 2 in the cloister garth II (edited by U. Bąk)

(pomimo zniszczeń rozebranym ostatecznie dopiero tuż przed rokiem 1250). Obserwacje stratygraficzne pomiędzy opisanym piecem a refektarzem wskazują też na znacznie późniejsze powstanie murów refektarza niż to do tej pory oceniano. Zapewne obiekt ten został zbudowany pod koniec lat 40. XIII wieku, tuż przed pierwszą wzmianką o istnieniu refektarza pochodzącą z roku 1250.

W otoczeniu kościoła Świętej Trójcy, po jego północnej, zachodniej i wschodniej stronie, odkryte zostały nasypy niwelacyjne z warstwami budowlanymi i piecami wapienniczymi, bezpośrednio związane z zaawansowaną fazą budowy ceglanego korpusu świątyni dominikańskiej na przełomie lat 40. i 50. XIII wieku (najprawdopodobniej przed II najazdem mongolskim w 1259 roku). W sekwencji nasypów budowlanych z połowy XIII wieku, otaczających kościół halowy, znaleziono liczne fragmenty cegieł o wymiarach główek 8,5-9×12 cm, w tym elewacyjnych o wymiarach główki $8 \times 11,5 \mathrm{~cm}$ i $9 \times$ ? $\mathrm{cm}$, pokrytych turkusową glazura, kształtek ceramicznych, dachówek ceramicznych typu mnich-mniszka i dachówek typu karpiówka, fragmentów półproduktów i gotowych późnoromańskich płytek posadzkowych bez śladów starcia powierzchni użytkowej. Ponadto w obrębie nasypów znaleziono fragmenty formowanych ręcznie, lekko łukowatych kształtek ceglanych o wymiarach główek $6-7 \times 15 \mathrm{~cm}$, z charakterystycznymi smugami na powierzchni, które wskazują, że zostały przed wypałem wyrównane 
czymś w rodzaju pędzla. Na jednej z kształtek widniał znak ceglarski w kształcie litery „Z”, odciśnięty sztancą. W tym kontekście należy zwrócić uwagę na dwa fragmenty płytek (ryc. 4) znalezionych w obrębie XIII-wiecznego wypełniska podpiwniczonej części budynku (nr 3), zniszczonego w wyniku najazdu mongolskiego w 1241 roku, który odkryty został przy fundamencie północnej ściany kaplicy św. Marii Magdaleny (Bojęś-Białasik, Niemiec 2013, s. 284-285). Przy dnie zasypiska obiektu (na głębokości $213 \mathrm{~cm}$ ) znaleziono fragment półproduktu późnoromańskiej płytki posadzkowej wykonanej w technice reliefowo-inkrustowanej, wypalonej w niskiej temperaturze na wstępnym etapie produkcji, bez śladów intencjonalnego szkliwienia oraz śladów starcia powierzchni użytkowej. Na analogiczny ślad miejscowej produkcji takich płytek natrafiono w tej samej sekwencji nasypów budowlanych, poniżej dna piwnicy budynku nr 3, w obrębie najniżej zalegającej części zasypiska beczki odwadniającej (na głębokości 343 $\mathrm{cm})$. Odkryto tam lepiej zachowany fragment półproduktu późnoromańskiej płytki posadzkowej (wielkości 1/4 całej płytki), wykonanej również w technice reliefowo-inkrustowanej, zdobionej reliefem z motywem lilii i plecionki, z tłem inkrustowanym różowo-kremową glinką. Egzemplarz ten wypalono w niskiej temperaturze, a w kolejnym etapie produkcji reliefowa ornamentacja została uzupełniona inkrustacja, która uległa utrwaleniu w wyniku drugiego wypału. Nie stwierdzono jednak śladów intencjonalnego szkliwienia płytki, a także jakichkolwiek śladów starcia powierzchni użytkowej.

W 1997 roku Teofil Dębowski w obrębie północnej części tzw. budowli romańskiej, w niewielkiej odległości od południowo-wschodniego narożnika III wirydarza (wykop IX/97), w nadcalcowej, późnośredniowiecznej warstwie kulturowej z XIV wieku, odkrył fragment ceramicznej płytki posadzkowej o wymiarach $17 \times 15 \times 3,5 \mathrm{~cm}$, pokrytej brązową polewą, bez śladów użytkowania, której wewnętrzny przełom w miejscu odłamania pokryty był szkliwem i na tej podstawie uznano ją za typowy odpad produkcyjny (Dębowski 1997a, s. 31, 40-41; Dębowski 1997ab s. 69, nr inw. 154/97; Szewczyk-Wojtasiewicz 1999, s. 155 , przypis 25 ).

Badania archeologiczne dostarczyły też kolejnych przekonujących dowodów na funkcjonowanie przy klasztorze i w otoczeniu kościoła wyspecjalizowanego warsztatu budowlanego. W wyniku prac wykopaliskowych przeprowadzonych na tzw. zachodnim dziedzińcu gospodarczym, przy zewnętrznej ścianie zachodniego krużganka odsłonięto pozostałości pieca (nr 6; ryc. 1, 5-7), który służył do wypalania wapna i wysokogatunkowych wyrobów ceramicznych - cegieł, kształtek ceglanych oraz płytek posadzkowych. Wzmiankowany obiekt zalegał pod najstarszymi wczesnogotyckimi fundamentami ściany zachodniej krużganka zachodniego i był wkopany w strop calca z poziomu humusu kopalnego. Ściana czołowa pieca, o szerokości 215 cm, wykonana została z szarej surówki ceglanej 

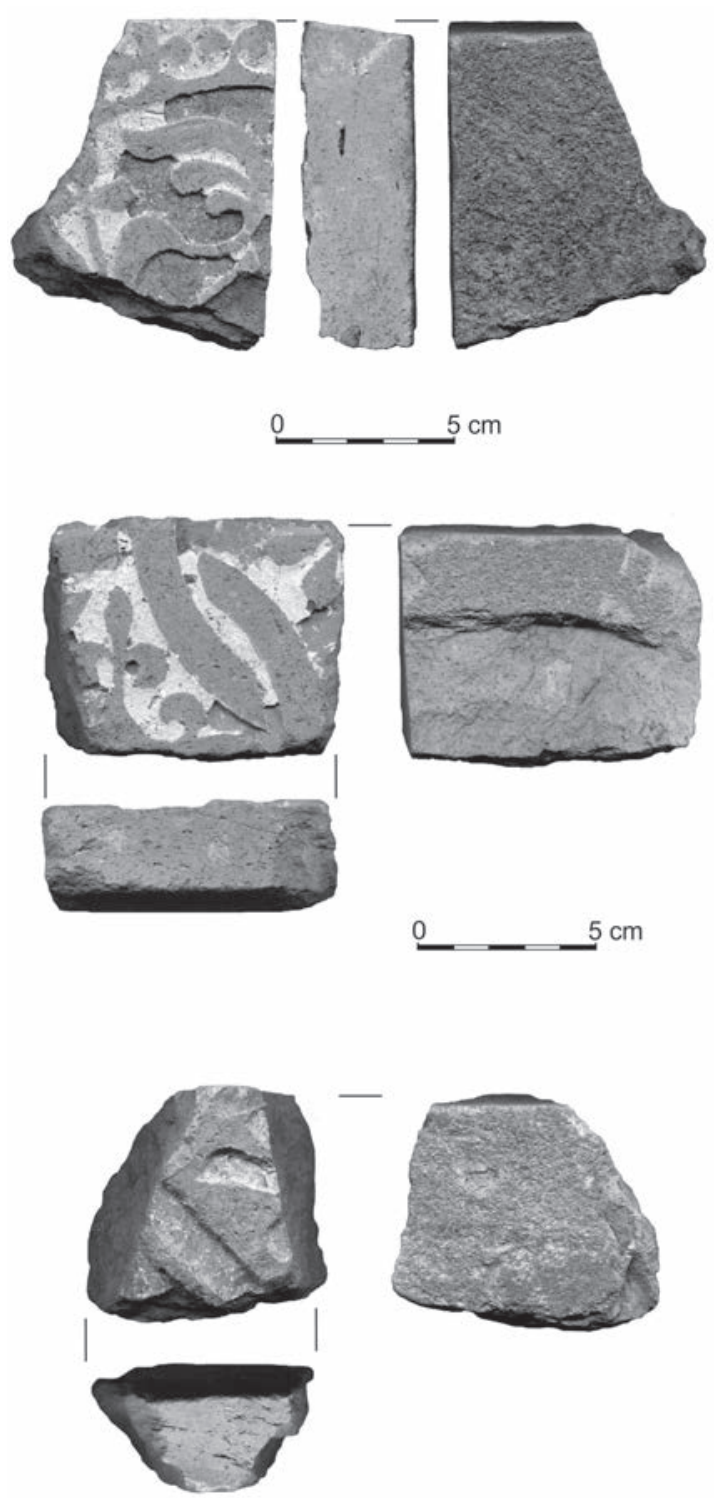

Ryc. 4. Fragmenty półproduktów ceramicznych płytek posadzkowych wykonanych w tzw. technice reliefowo-inkrustowanej, bez śladów pokrycia powierzchni użytkowej szkliwem, odkryte w warstwach i nasypach budowlanych wokół kościoła Św. Trójcy w Krakowie, datowanych po 1241 roku (oprac. graf. U. Bąk)

Fig. 4. Fragments of semi-finished ceramic floor tiles made in the so-called relief-inlay technique with no traces of glaze on the the usable surface, unearthed in layers and construction embankments around the church of St Trinity in Krakow, dated to after 1241 (edited by U. Bąk) 


\section{ZACHODNIE SKRZYDŁO KRUŻGANKÓW}

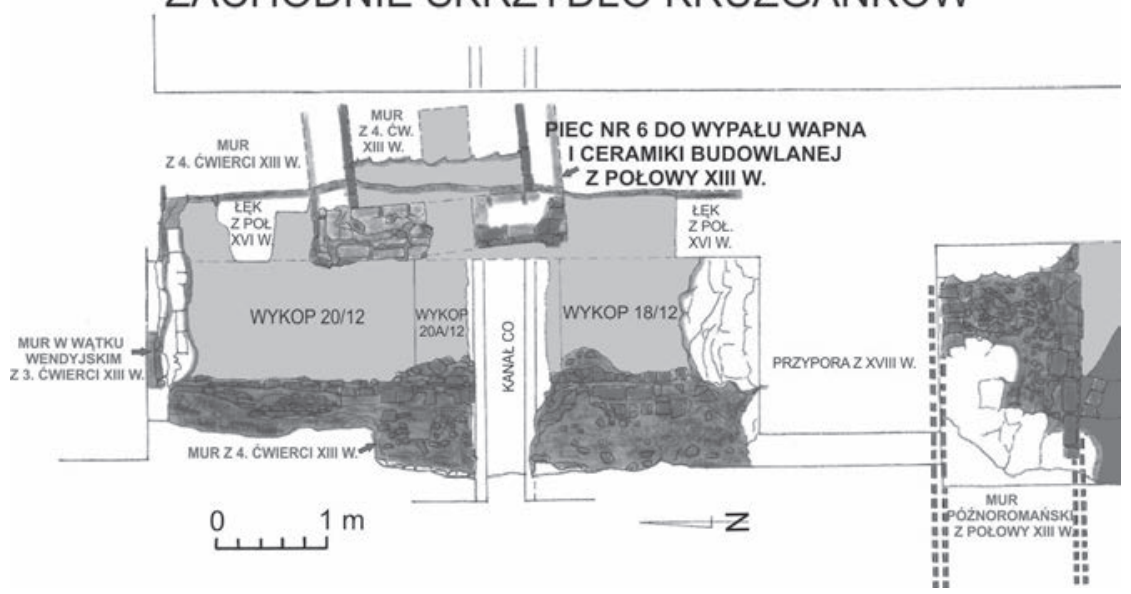

Ryc. 5. Kraków, klasztor Dominikanów. Plan z reliktami pieca produkcyjnego nr 6 z połowy XIII wieku, odkrytymi przy zachodniej ścianie zachodniego krużganka (oprac. D. Niemiec)

Fig. 5. Krakow, Dominican monastery. Plan with the remains of kiln No. 6 from the mid- $13^{\text {th }}$ century, discovered at the western wall of the western cloister (edited by D. Niemiec)

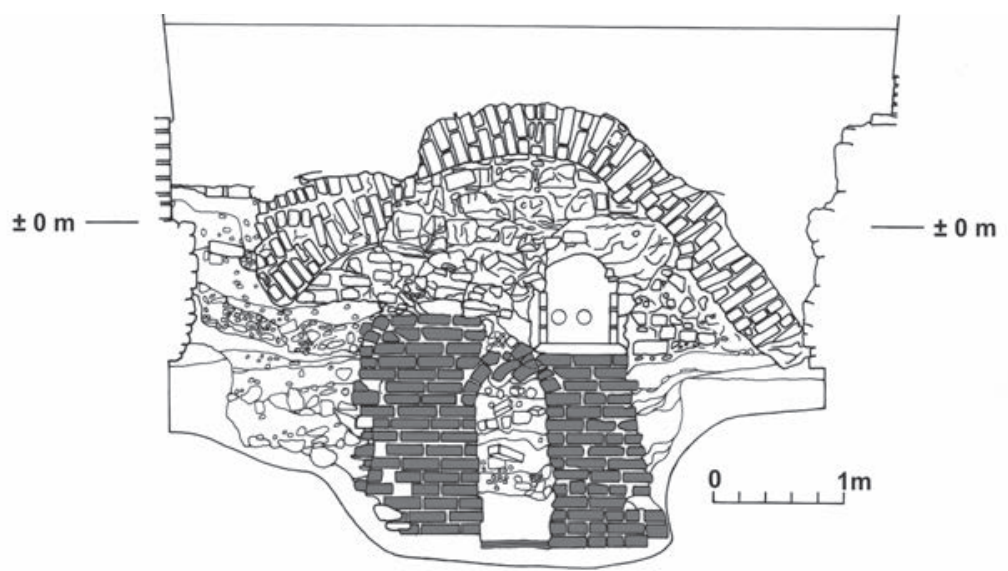

Ryc. 6. Kraków, klasztor Dominikanów. Relikty ściany czołowej pieca produkcyjnego nr 6 z wlotem do komory paleniskowej, przeznaczonego do wypału wapna i późnoromańskiej ceramiki budowlanej, w tym płytek posadzkowych, z połowy XIII wieku, odkryte przy zachodniej ścianie zachodniego krużganka (oprac. D. Niemiec)

Fig. 6. Krakow, Dominican monastery. Remains of the front wall of kiln No. 6 with the inlet to the fire chamber for lime firing as well as late Romanesque construction ceramics including floor tiles from the mid- $13^{\text {th }}$ century, discovered at the western wall of the western cloister (edited by D. Niemiec) 

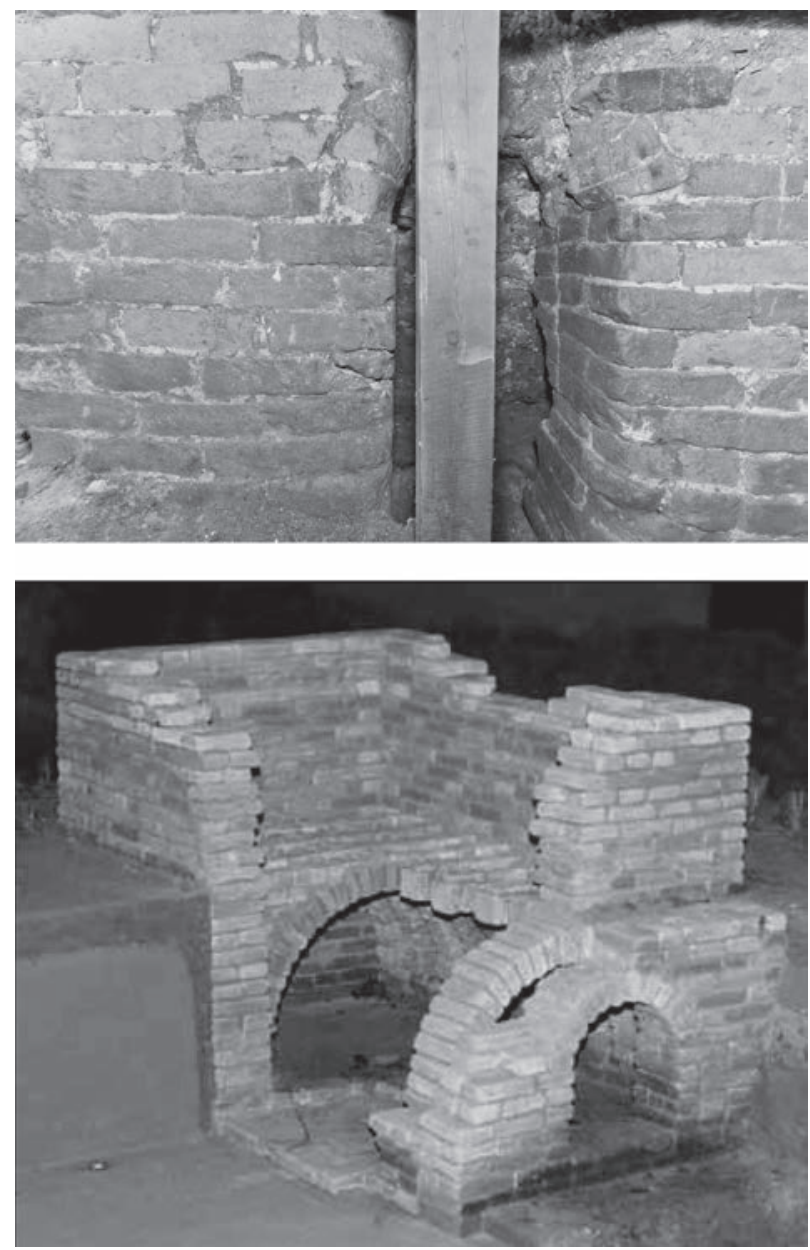

Ryc. 7. Ściana czołowa pieca nr 6 do wypału płytek posadzkowych z klasztoru Dominikanów w Krakowie z widocznym wlotem do komory paleniskowej (A) oraz model z rekonstrukcją identycznego pieca produkcyjnego odkrytego w Utrechcie (B) (fot.: u góry - L. Modelski; u dołu - wg Oosten 2012)

Fig. 7. Front wall of kiln No. 6 for firing floor tiles from the Dominican monastery in Krakow with a visible inlet to the fire chamber (A) and a model with the reconstruction of an identical kiln discovered in Utrecht (B) (photo by: top - L. Modelski; bottom - after Oosten 2012)

i wypalonych cegieł" ${ }^{7}$ wiązanych w jednolitą strukturę murowaną na zaprawie wapiennej. Pośrodku ściany znajdował się otwór wlotowy do komory paleniskowej, o szerokości 55 cm, który przykryty był uszkodzonym łękiem wykonanym z surowych, niewypalonych klińców - surówki ceglanej (ryc. 5-7). Mur ściany czołowej

${ }^{7}$ Wymiary cegieł: 8,5×13,5-14,5×28,5-29 cm i 9×12,5-14,5×27-28,5 cm. 
pieca oraz jego mury poprzeczne miały grubość 40-44 cm, szerokość wnętrza komory paleniskowej wynosiła 164 cm, a drugi jej wymiar (długość?) przekraczał $80 \mathrm{~cm}$, gdyż na taką długość wyeksplorowano wypełnisko wnętrza pieca. W zewnętrznym obrysie ściana czołowa pieca miała szerokość $215 \mathrm{~cm}$, zaś długość dostawionych do niej murów poprzecznych przekraczały $140 \mathrm{~cm}$. Wewnątrz pieca stwierdzono wyraźne ślady jego użytkowania - okopcenia ścian i przepalonej ziemi na dnie komory paleniskowej. Część surówki ceglanej użytej do budowy ścian pieca nie uległa wypaleniu, co należy tłumaczyć krótkim okresem użytkowania obiektu. W wypełnisku komory pieca stwierdzono zalegające naprzemiennie warstwy szarej gliny i wypalonego wapna oraz kamieni wapiennych. W ich obrębie natrafiono na kilka fragmentów cegieł ${ }^{8}$ popękanych od działania wysokiej temperatury, w niektórych spękaniach zaobserwowano wlane szkliwo, między innymi w kształtkach ceramicznych (o wysokości 5,5-6 cm) czy narożnej płytce posadzkowej (o grubości 5,5 cm i szerokości $17 \mathrm{~cm}$ ). W wypełnisku komory pieca, także na dnie obiektu, znaleziono półprodukty i źle wypalone, popękane późnoromańskie płytki posadzkowe. Wśród nich były: płytka z motywem plecionki, wykonana w technice reliefowo-inkrustowanej ze śladami termicznych spękań, bez śladów pokrycia glazura, płytka z motywem plecionki i lilii (nieudany wypał), wykonana w technice reliefowo-inkrustowanej, pokryta glazurą, ze śladami spękań, płytka z motywem czteroramiennej gwiazdy (nieudany wypał), wykonana w technice reliefowo-inkrustowanej, z zachowanym spękanym szkliwem oraz - znaleziona przy dnie pieca - płytka z motywem plecionki (półprodukt), wykonana również w technice reliefowo-inkrustowanej, bez śladów szkliwienia, ze śladami spękań i wykruszoną inkrustacją (ryc. 8). Z wypełniska komory pieca wydobyto też bryłkę szlaki miedzianej, używanej po wytopieniu i rozdrobnieniu jako dodatek do tzw. glejty ołowianej przy produkcji szkliwa o zielonej barwie. Ściana czołowa pieca wokół wlotu do komory paleniskowej miała starannie wykonane lico, natomiast mury poprzeczne ułożono bez zachowania równej powierzchni, tak jak typowe mury fundamentowe wykonane w tzw. ścisłym wkopie. Na zewnątrz komory wlotowej natrafiono na rodzaj jamy przypiecowej wypełnionej warstwą wapna z kamieniami wapiennymi oraz warstwą szarej gliny zalegającej na dnie jamy. Na podstawie szeregu przesłanek archeologicznych opisany piec można datować przed połową XIII wieku, najprawdopodobniej na początek lat 40. XIII wieku (po 1241 roku).

W kontekście opisanego powyżej pieca do wypału płytek posadzkowych szczególną uwagę należy zwrócić na niemal identyczny obiekt z pojedynczą, zagłębioną w ziemię komorą paleniskową, odkryty wraz z półproduktami płytek w holenderskim Utrechcie, na stanowisku Bemuurde Weerd (ryc. 7); jego chronologię określono na połowę XIV wieku (Rooyen van 2008, s. 66, 72, ryc. 2, 3; Oosten van 2012, s. 144, ryc. 4). Jeden z najwcześniejszych średniowiecznych

${ }^{8}$ Wymiary cegieł: $7,5 \times 12 \times 27 \mathrm{~cm}, 8 \times 13,5 \mathrm{~cm}, 8 \times 12 \mathrm{~cm}, 8,5 \times 12 \mathrm{~cm} \mathrm{i} 9 \times 12,5 \mathrm{~cm}$. 
pieców do wypału cegieł i detali ceramicznych, w tym płytek posadzkowych, który nawiązuje do modelowych rozwiązań gallo-rzymskich z pojedynczym, centralnie umieszczonym wlotem do dwudzielnej komory paleniskowej odkryty został na terenie Italii w klasztorze benedyktyńskim San Vinceznzo al Volturno, wśród obiektów datowanych na 1 . ćwierć IX wieku (Tonezzer 2002, s. 104, ryc. 2). Wyraźnie odmienny i młodszy typ pieca do produkcji ceramiki budowlanej, z dwoma komorami paleniskowymi, rozpoznany został wykopaliskowo w obrębie opactwa cysterskiego w Altzella w Niemczech (Saksonia); powiązano go z początkami budowy klasztoru na przełomie XII i XIII wieku (Tonezzer 2002, s. 107). Bez wątpienia najlepiej zachowany i przebadany tego typu obiekt z połowy XIII wieku, związany z produkcją płytek posadzkowych, pochodzi z opactwa cysterskiego w North Grange w Anglii (Eames 1961, s. 141-163, 166-167, ryc. 41-44). W Europie Środkowej taki wyjątkowy piec z XIII wieku, interpretowany jako element cegielni, odsłonięto przy klasztorze Norbertanów w czeskim Milevsku (Drda 1983, s. 167-173, ryc. 1-3). Analogiczne jak w Altzella czy North Grange piece z dwukomorowymi paleniskami, użytkowane w 1. połowie XIV wieku, pochodzą z angielskich stanowisk w Penn (Haton 2009, s. 1-3) i klasztoru Kanoników Regularnych w Repton (Lemmen van 2010, s. 4), niemieckich w Dambach-Neunhoffen (Alzacja) i Haldensleben, czy z Kölliken i Pfäfers/Ragol z terenu Szwajcarii (Tonezzer 2002, ryc. 4, 5, 8, 10) ${ }^{9}$. Z okresu średniowiecza znane są też przykłady takich pieców produkcyjnych z trzema komorami paleniskowymi. Najwcześniejsze obiekty o tak rozbudowanej strukturze paleniska, pochodzące z XIII wieku, odkryto w Londynie przy Farringdon Road (Betts 2002, s. 8, ryc. 2) i w węgierskim Tiszalök-Kövestelken (Attila 2011, s. 158-159, ryc. 17), a nieco młodsze w niemieckim Öhringen-Michelbach z XV/XVI wieku oraz francuskim Soirans-Fouffrans, gdzie piec datowany jest od początku XV do XVII wieku (Tonezzer 2002, s. 107-109, ryc. 6, 7).

Podobnie, jak w przypadku pieca do produkcji płytek ceramicznych odkrytego w 2014 roku, należy interpretować analogiczne struktury z niewypalonej cegły (surówki ceglanej), spojonej zaprawą wapienną, odsłonięte na terenie klasztoru Dominikanów w Krakowie podczas badań prowadzonych w latach 60. XX wieku przez Andrzeja Żakiego i Mieczysława Frasia (piec nr 1; ryc. 1, 9). Na pozostałości tego obiektu natrafiono w wykopie I/62, założonym w części dziedzińca gospodarczego usytuowanej bardziej na północ (Żaki 1965a, s. 283, ryc. 1, 2; por. też Piątkiewicz-Dereniowa 1971, s. 261). Z zachowanego oryginalnego dziennika badań prowadzonego przez M. Frasia wynika, że wykop I/62 docelowo osiągnął wymiary $3 \times 5 \mathrm{~m}$ i znajdował się w odległości $2 \mathrm{~m}$ od lica ściany pralni klasztornej, zaś strop pieca z murem wykonanym z surówki ceglanej odsłonięto na głębokości 190-205 cm poniżej współczesnego poziomu terenu. Piecowi (piecom ?) odkrytym w 1962 roku

${ }^{9}$ Rekonstrukcja takiego średniowiecznego pieca do wypału płytek z dwoma komorami paleniskowymi - por. Norton 1992, ryc. 11. 

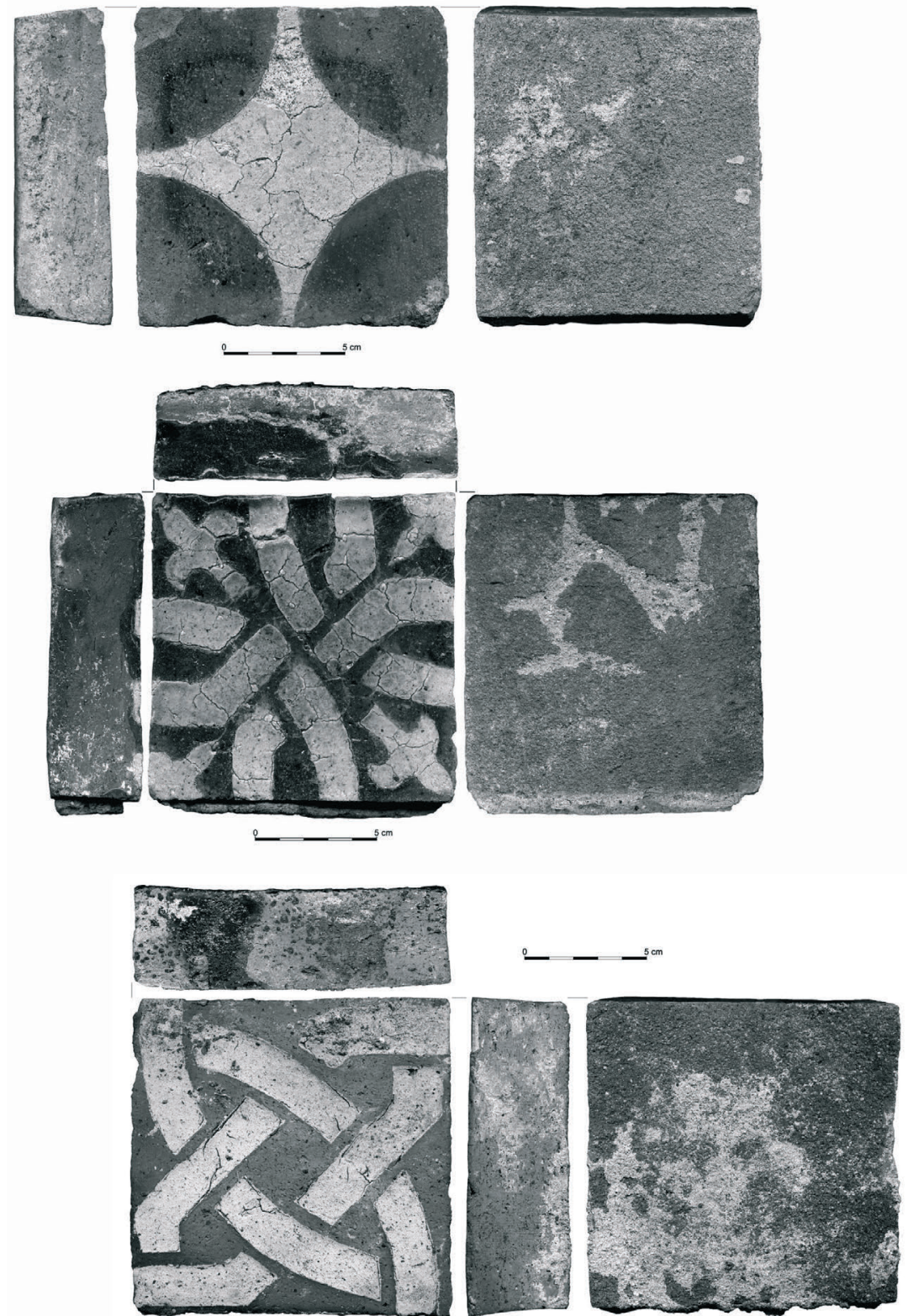

Ryc. 8. Kraków, klasztor Dominikanów. Półprodukty późnoromańskich płytek posadzkowych wykonanych w technice reliefowo-inkrustacyjnej, pochodzące z wnętrza pieca nr 6, odkrytego przy zachodnim krużganku (oprac. U. Bąk)

Fig. 8. Krakow, Dominican monastery. Semi-finished late Romanesque floor tiles made in the relief-inlay technique originating from the interior of kiln No. 6, discovered at the western cloister (edited by U. Bąk) 


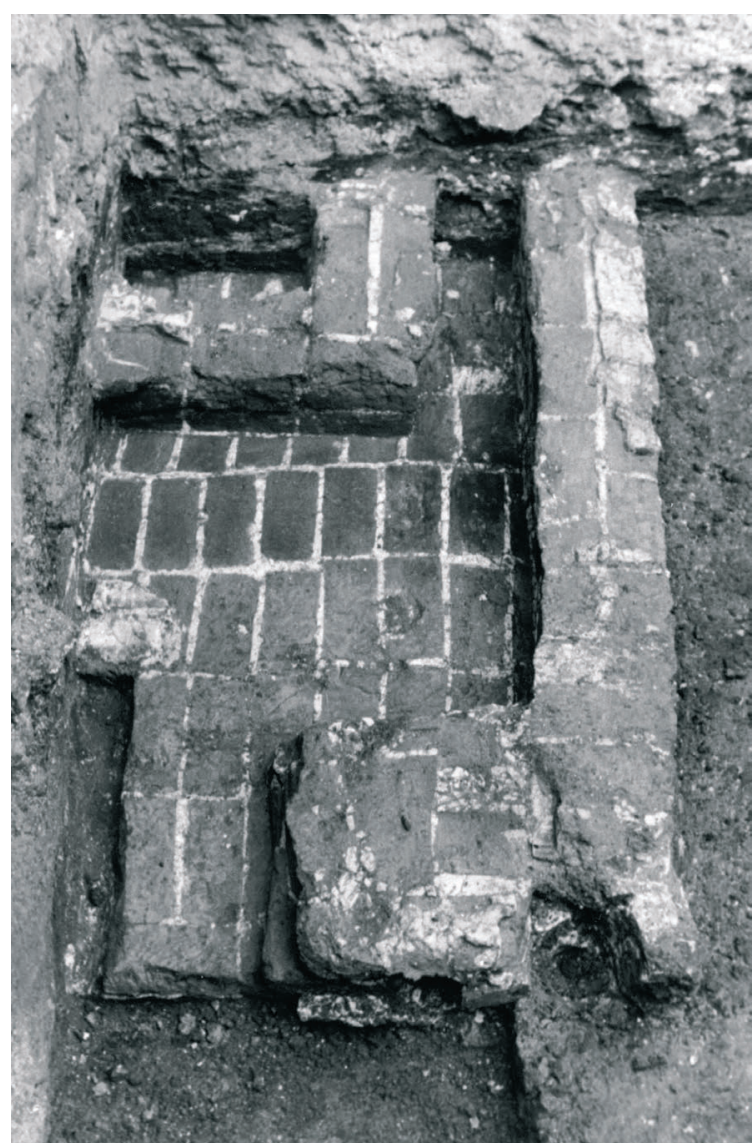

Ryc. 9. Kraków, klasztor Dominikanów. Elementy struktury domniemanego pieca nr 1, wykonanego z „niewypalonej cegły” (surówki ceglanej), łączonej zaprawą wapienną, odsłonięte w 1962 roku przez A. Żakiego w północnej części tzw. dziedzińca gospodarczego w zachodniej części klasztoru (niepublikowana fotografia autorstwa M. Frasia z dawnych zbiorów Działu Archeologii Zamku Królewskiego na Wawelu)

Fig. 9. Krakow, Dominican monastery. Elements of the structure of the presumed kiln No. 1, made of 'unfired brick', joined by lime mortar, discovered in 1962 by A. Żaki in the northern part of the so-called economic yard in the western part of the monastery (unpublished photo by $\mathrm{M}$. Fraś from the former collections of the Department of Archaeology of the Royal Castle at Wawel)

towarzyszyły również liczne znaleziska późnoromańskich płytek posadzkowych (Żaki 1963, s. 599, 601, ryc. 17, 18; 1965a, s. 283, ryc. 6; 1965b, ryc. 75, 76; Szewczyk-Wojtasiewicz 2006a, s. 388-389, noty nr 8 i 9) z największą ich koncentracją na głębokości 165-185 cm. Andrzej Żaki chronologię odkrytych wówczas przez siebie obiektów produkcyjnych określił na schyłek okresu przedlokacyjnego (1. 
połowa XIII wieku), na co miał wskazywać denar Henryka, biskupa Utrechtu, wybity w latach 1250-1262, znaleziony w spągu warstwy związanej z destrukcją tych struktur (Żaki 1965, s. 283). Jak wynika z notatek terenowych i zachowanej metryczki wspomniana moneta srebrna, zidentyfikowana jako denar biskupi, znaleziona została na głębokości $205-215 \mathrm{~cm}$. Maria Piątkiewicz-Dereniowa, odwołując się do opisanych odkryć A. Żakiego wyraziła jako pierwsza pogląd o produkcji późnoromańskich płytek posadzkowych z Krakowa w warsztacie działającym przy klasztorze Dominikanów (Piątkiewicz-Dereniowa 1971, s. 261). Wskazała przy tym na fakt odkrycia w 1954 roku przez zespół A. Żakiego na dziedzińcu gospodarczym tego klasztoru ceramicznych donic szklarskich, uszkodzonych w czasie wytopu szkła i powiązała tę grupę znalezisk z produkcją szkła witrażowego, stosowanego również w średniowieczu do pokrywania wyrobów ceramicznych wielobarwną polewą (Piątkiewicz-Dereniowa 1971, s. 261).

W kontekście opisanych wyżej pieców produkcyjnych odkrytych w Krakowie warto też zwrócić uwagę na fakt, że analogiczny obiekt ze ścianami zbudowanymi z niewypalonej i spojonej lessem cegły, odsłonięto w Sandomierzu, w kontekście wczesnych nawarstwień z 2. ćwierci XIII wieku, związanych z początkami budowy dominikańskiego kościoła św. Jakuba i powiązanego z nim wschodniego skrzydła klasztoru (Florek 1993, s. 122, 136, ryc. 3, 7; 1994, ryc. 14, 15).

Z kolei po południowej stronie krakowskiego kościoła Dominikanów, na terenie obecnego zaplecza posesji przy ulicy Dominikańskiej 1, odkryto stanowisko strycharza z połowy XIII wieku wraz ze składem surówki ceglanej i owalnym piecem do wypału ceramiki (piec nr 5; ryc. 1, 10). Kopułkowa konstrukcja tego obiektu o wymiarach $150 \times 130 \mathrm{~cm}$ wykonana została z drewnianego, plecionego szkieletu oblepionego gliną. Przy piecu znaleziono skład z cegłą i surówką ceglaną o wymiarach $8,5 \times 11,5-12 \mathrm{~cm}$ i $9-9,5 \times 12,5-13 \mathrm{~cm}$. W jego otoczeniu odkryto też dwa fragmenty późnoromańskich płytek posadzkowych, które stanowiły odpady produkcyjne (ryc. 11) oraz fragment glazurowanej dachówki karpiówki. Wzmiankowany warsztat strycharza odsłonięty został na głębokości 450-590 cm i zalegał bezpośrednio na zasypisku fosy podgrodzia krakowskiego zwanego Okołem. Obiekt ten, odkryty po południowo-zachodniej stronie kościoła Dominikanów, daleko poza klauzurową zabudową klasztorną, zapewne miał bezpośredni związek z próbą zakończenia budowy korpusu kościoła halowego, zainicjowanej około połowy XIII wieku i - jak może wskazywać porzucenie tego stanowiska produkcyjnego przez strycharza - przerwana została na stosunkowo zaawansowanym etapie, ale na pewno nie była dokończona przed drugim najazdem mongolskim w 1259/1260 roku.

Po północnej stronie kościoła klasztornego, w obrębie pomieszczenia przy północnej ścianie kaplicy św. Marii Magdaleny, pomiędzy sekwencją nasypów budowlanych, odkryto pozostałości pieca wapienniczego w postaci rumowiska glinianej kopuły oraz glinianego klepiska zachowanego in situ wraz z dolnymi 

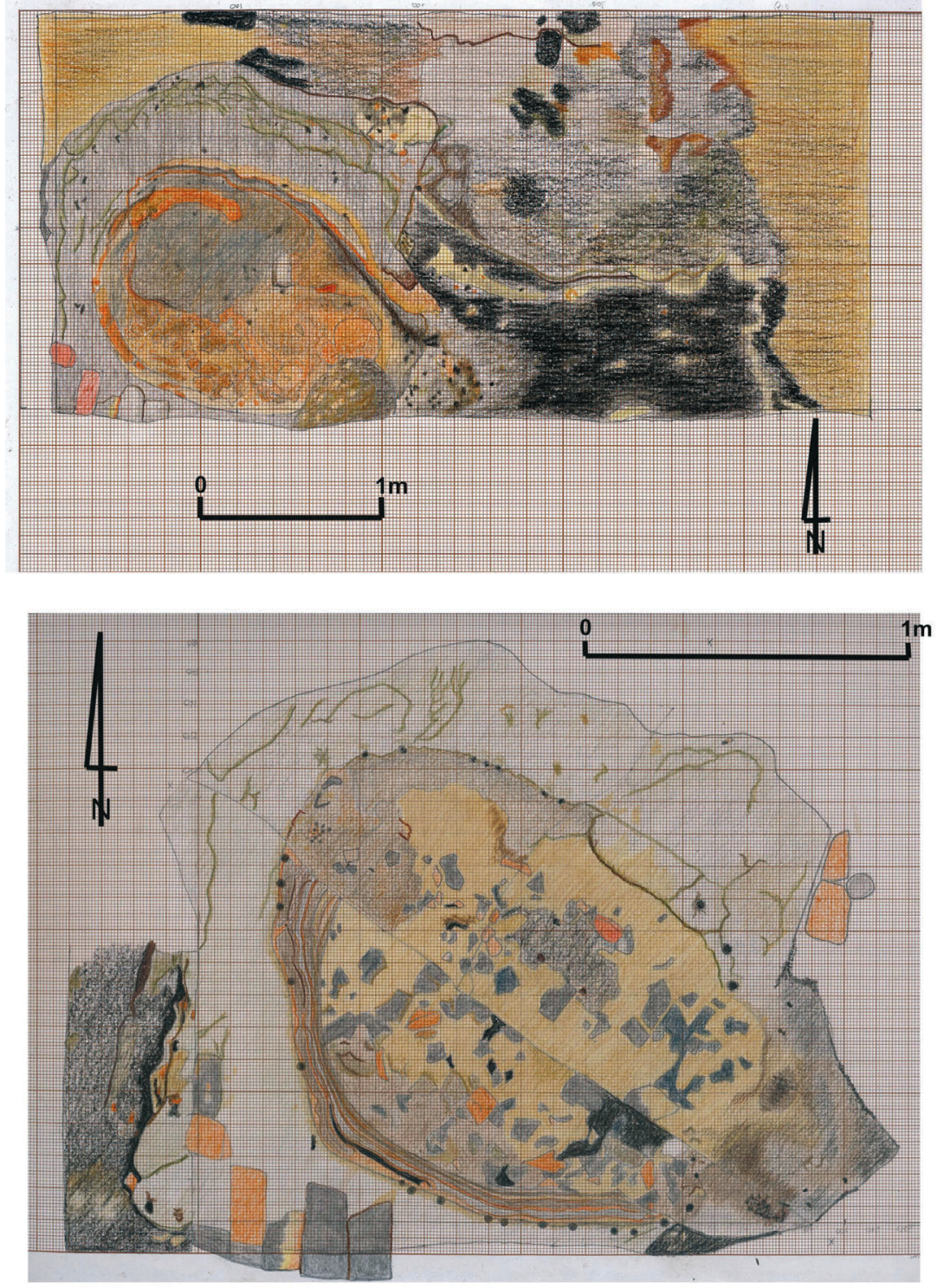

Ryc. 10. Kraków, ul. Dominikańska 1. A - wykop I/12: rzut z reliktami drugiej fazy pieca nr 5 do wypału ceramiki naczyniowej i budowlanej; B - plecionkowa konstrukcja ścianek starszej fazy tego pieca wraz ze składem surówki ceglanej, z połowy XIII wieku (rys. B. Zając)

Fig. 10. Krakow, ul. Dominikańska 1. A - trench I/12: plan with the remains of the second phase of kiln No. 5 for firing pottery and construction ceramics; B - wattle walls construction of the older phase of this kiln together with charge of unfired bricks from the mid- $13^{\text {th }}$ century (drawing by B. Zając) 

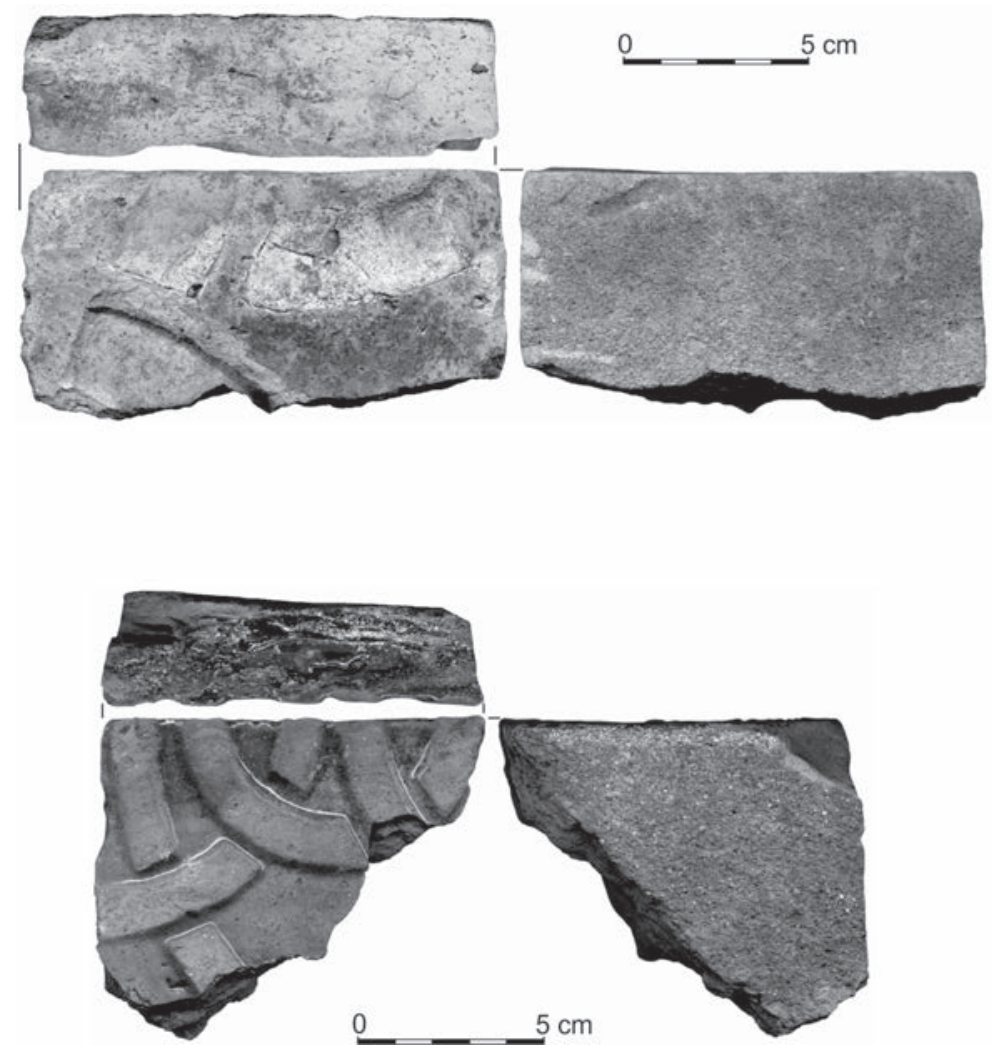

Ryc. 11. Kraków, ul. Dominikańska 1. A - półprodukt późnoromańskiej płytki posadzkowej wykonanej w technice reliefowo-inkrustacyjnej, bez śladów pokrycia szkliwem; B - fragment szkliwionej płytki posadzkowej przepalonej i uszkodzonej na wskutek działania wysokiej temperatury na ostatnim etapie wypału po nałożeniu szkliwa odkryte w sąsiedztwie reliktów pieca nr 5 (oprac. U. Bąk)

Fig. 11. Krakow, ul. Dominikańska 1. A - late Romanesque floor tile made in the relief-inlay technique, with no traces of glaze; B - fragment of glazed floor tile over-fired and damaged by the effects of high temperature on the last stage of firing after glazing found in the vicinity of the remains of kiln No. 5 (edited by U. Bakk)

partiami ścianek obiektu (piec nr 4; ryc. 1, 12). Na podstawie zachowanych reliktów można stwierdzić, że wspomniany piec o owalnym kształcie w rzucie poziomym miał wymiary $240 \times 140 \mathrm{~cm}$. Na dnie komory paleniskowej odkryto warstwę wypalonego wapna wraz z przepalonymi i popękanymi kamieniami wapiennymi oraz fragmentami świeżo wypalonych wczesnośredniowiecznych naczyń ceramicznych. Wynika z tego jednoznacznie, że piec użytkowany był przede wszystkim do wypalania wapna, a incydentalnie także naczyń ceramicznych. Sam obiekt na podstawie znalezionej i wypalanej w nim ceramiki oraz określonego na podstawie kontekstu stratygraficznego terminus post quem, należy datować bezpośrednio 


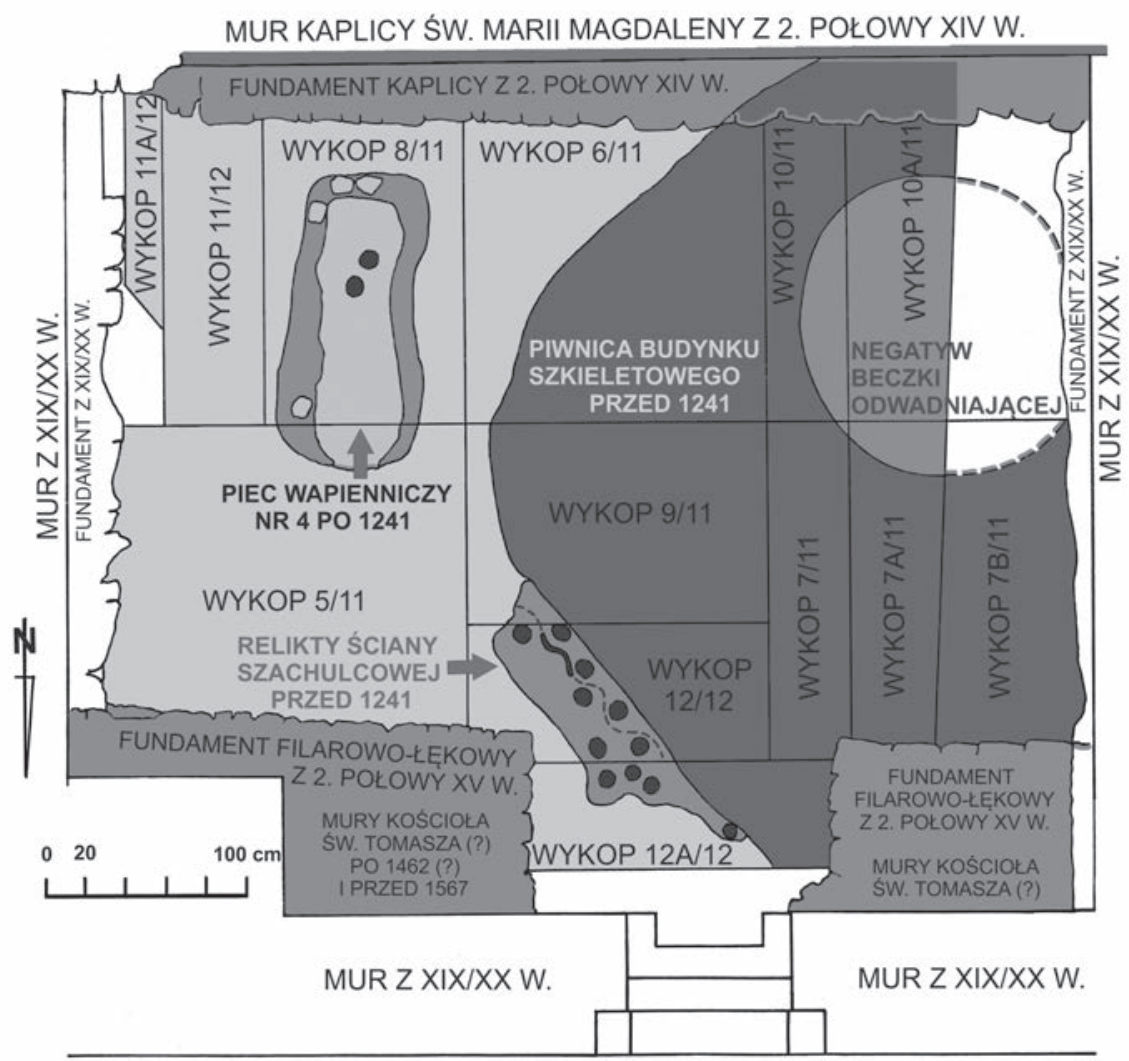

Ryc. 12. Kraków, kościół Dominikanów. Plan z reliktami pieca wapienniczego nr 4 z połowy XIII wieku, odkrytymi przy kaplicy św. Marii Magdaleny (oprac. D. Niemiec)

Fig. 12. Krakow, Dominican church. Plan with the remains of limekiln No. 4 from the mid- $13^{\text {th }}$ century, unearthed at the chapel of St Mary Magdalene (edited by D. Niemiec)

przed połową XIII wieku i na pewno po pierwszym najeździe mongolskim w 1241 roku, gdyż bezpośrednio pod klepiskiem pieca odkryto starszą stratygraficznie warstwę spalenizny z grocikami mongolskimi.

Po zachodniej stronie kościoła, w bezpośrednim sąsiedztwie kaplicy Lubomirskich w kontekście warstw XIII-wiecznych odkryto kolejny gliniany piec kopułkowy ze śladami wypalania wapna (piec nr 8; ryc. 1). Miał on kształt owalu o wymiarach $120 \times 150 \mathrm{~cm}$, a jego ścianki zachowane były do wysokości $100 \mathrm{~cm}$ (Łyczak, Górski 2012, s. 239-240, ryc. 10; Łyczak, Górski 2013, s. 251-252, ryc. 11, 12; Rojkowska 2014, s. 114, ryc. 15).

W południowo-wschodniej części III wirydarza, na głębokości 160-280 cm stwierdzono, relikty pieca produkcyjnego (wapienniczego?) z otworem wlotu do komory o szerokości $90 \mathrm{~cm}$, wypełnionej wapnem i kamieniami wapiennymi 
(piec nr 3; ryc. 1, 13). Miał on ściany wykonane z cegieł spojonych gliną ${ }^{10}$, w niektórych partiach zachowane do wysokości 8-9 warstw cegieł. Od zewnatrz ściany otulone były kamiennym murem wykonanym z brył wapienia, spojonych zaprawą wapienną (akumulator ciepła?). Z funkcjonowaniem i obsługą tego pieca należy łączyć odkryty obok niego, na głębokości 170-180 cm, poziom nieckowatej posadzki wykonanej z cegieł ${ }^{11}$, przykrytej pierwotnie zadaszoną wiata, z potwierdzoną archeologicznie konstrukcją dachu opartą na słupach (miejsce suszenia gliny i surówki ceglanej przed wypałem?). Do wzniesienia ścian pieca użyto wtórnie kształtki ceramiczne (o wymiarach 8,5×13×28-34 cm), stanowiące elementy fryzu zębatego oraz prostego wzoru fryzu arkadkowego, analogicznego do fryzów znanych z kościoła Dominikanów w Sandomierzu czy kościoła Cystersów w Mogile. W ścianach stwierdzono także wtórne wykorzystanie elewacyjnych cegieł pokrytych turkusową glazurą (o wymiarach 8,5-9×13 cm, które prawdopodobnie należy łączyć z wystrojem niezachowanych romańskich portali kościoła Dominikanów krakowskich, analogicznych z kolorowym, glazurowanym wystrojem głównego portalu w sandomierskim kościele św. Jakuba. Pod reliktami pieca natrafiono na zasypisko starszego obiektu typu ziemianka, w którym znaleziono fragmenty późnoromańskich płytek ceramicznych, co stanowi też terminus post quem dla określenia czasu budowy pieca. Na podstawie kontekstu stratygraficznego oraz cegieł i kształtek ceramicznych wykorzystanych w konstrukcji ścian pieca można go datować najwcześniej na przełom lat 40. i 50. XIII wieku. Relikty ceglanych ścian łączonych na glinie z kamienną otuliną i otaczających tę strukturę rozległych połaci posadzek mogą być interpretowane jako elementy wyposażenia dużego pieca produkcyjnego z towarzyszącą mu infrastrukturą dobrze wyizolowanego zaplecza (posadzka, zadaszenie), związanego najprawdopodobniej z suszeniem surówki ceglanej przeznaczonej do wypału.

W północno-wschodniej części III wirydarza, na głębokości 120-190 cm, odkryto relikty kolejnego pieca do produkcji wczesnogotyckiej ceramiki budowlanej (piec nr 2; ryc. 1, 14, 15); jego ściany i posadzkę wykonano z cegieł ${ }^{12}$. W zawalisku pochodzącym z domniemanej komory wypałowej tkwiły niewielkie kamienie wapienne, fragmenty cegieł palcówek i dachówek karpiówek oraz kilka kształtek ceramicznych - elementów wczesnogotyckich żeber sklepiennych o profilu gruszkowatym z XIII wieku (ryc. 15, 16). Kształtki sygnowane były na bocznej powierzchni znakiem warsztatowym (montażowym?) w formie krzyża greckiego i pozbawione jakichkolwiek śladów wcześniejszego użycia. Na dnie komory paleniskowej stwierdzono koncentrację warstwy wapna, co może wskazywać na

${ }_{10}$ Wymiary cegieł: $7,5 \times 12,5 \times 28 \mathrm{~cm}, 7,5 \times 13 \times 27 \mathrm{~cm}, 8 \times 13 \times 26,5 \mathrm{~cm}, 8,5 \times 13 \times 27,5 \mathrm{~cm}$, $9 \times 13,5 \times 28 \mathrm{~cm}, 9,5 \times 12,5 \times 27 \mathrm{~cm}, 9,5 \times 13,5 \times 28 \mathrm{~cm}$.

11 Wymiary ciegieł: 7,5×12,5 cm, 7,6×13 cm, $8 \times 13 \times 27,5 \mathrm{~cm}, 8,5 \times 13 \times 27,5-28 \mathrm{~cm}, 9 \times 13,5 \times 28 \mathrm{~cm}$.

12 Wymiary cegieł: $8,5 \times 14 \times 28,5 \mathrm{~cm}, 8,5 \times 13,5 \times 26 \mathrm{~cm}, 10 \times 13,5 \mathrm{~cm}, 9 \times 13,5 \times 28,5 \mathrm{~cm}$, $9,5 \times 13,5 \mathrm{~cm}, 9,5 \times 13 \mathrm{~cm}, 10 \times 13,5 \mathrm{~cm}, 10 \times 14 \mathrm{~cm}$. 


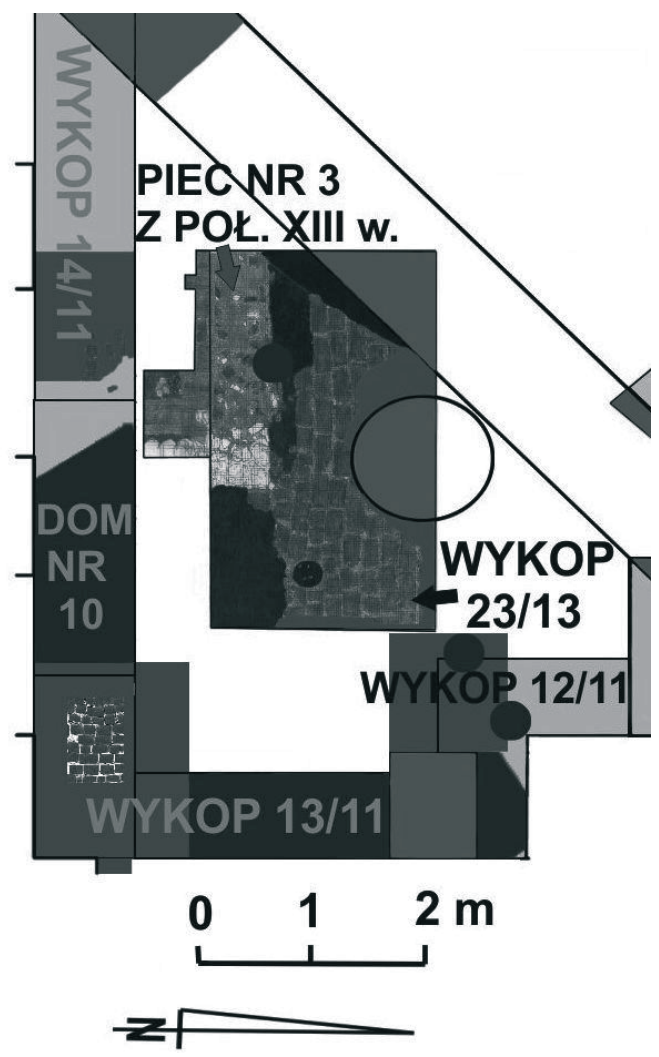

Ryc. 13. Kraków, klasztor Dominikanów. Plan z reliktami pieca nr 3 z połowy XIII wieku oraz odkrytymi w południowo-wschodniej części III wirydarza (oprac. D. Niemiec)

Fig. 13. Krakow, Dominican monastery. Plan with the remains of kiln No. 3 from the mid- $13^{\text {th }}$ century, discovered in the south-eastern part of the cloister garth III (edited by D. Niemiec)

równoległe z wypalaniem ceramiki budowlanej wykorzystywanie obiektu jako pieca wapienniczego. Na podstawie relacji stratygraficznych i formatu cegieł użytych do budowy pieca oraz kształtek wczesnogotyckich, a także jego znacznego oddalenia w stosunku do starszych pieców odkrytych na terenie klasztoru, obiekt należy datować na 3. ćwierć XIII wieku - lata 60. i 70. XIII wieku. Jednak na podstawie planigrafii oraz odniesienia do chronologii budowli klasztornej z wczesnogotyckimi kształtkami żeber, identycznymi jak odkryte w opisanym piecu (ryc. 16) (Frazik 1978, s. 253, ryc. 2G; Szyma 2004, s. 58, ryc. 71; Bojęś-Białasik, Niemiec 2016a, s. 242; 2016b, s. 40-41, ryc. 14), możliwe jest zawężenie jego datowania do czasów bezpośrednio po drugim najeździe mongolskim w 1259 roku. Funkcjonowanie tego pieca miało bezpośredni związek z wczesnogotycką przebudową wolno stojącej budowli romańskiej, wzniesionej w sąsiedztwie 


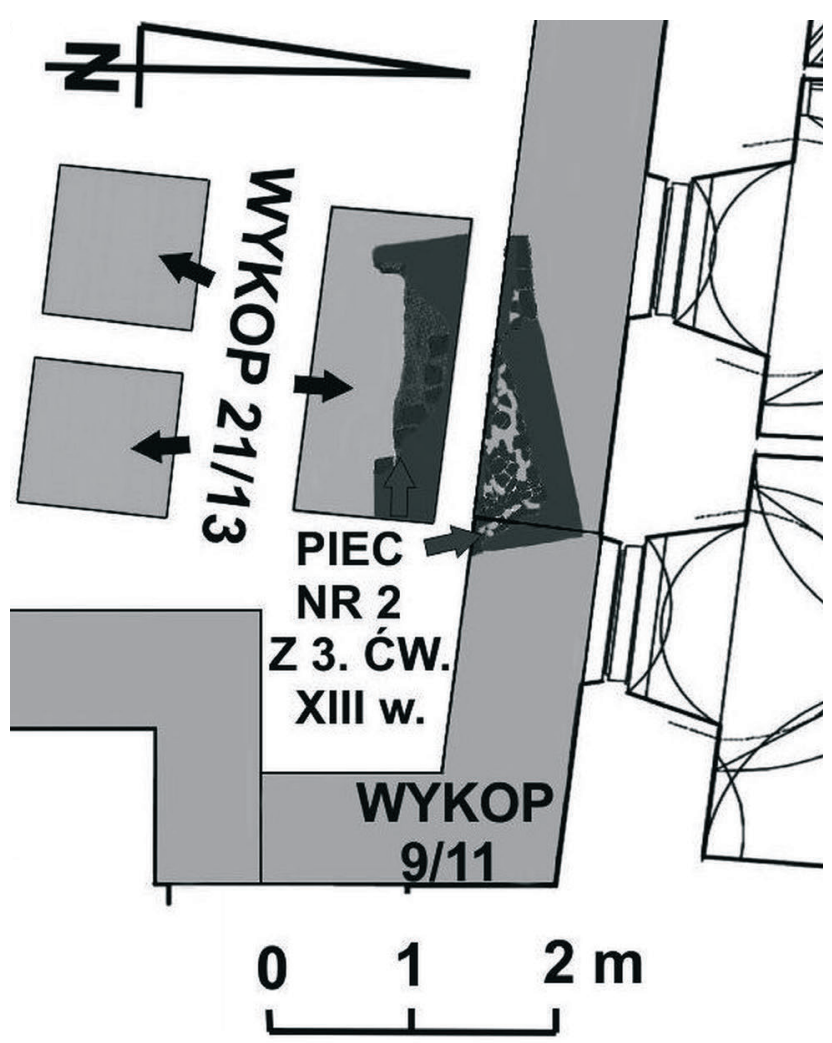

Ryc. 14. Kraków, klasztor Dominikanów. Plan z reliktami pieca nr 2 z 3. ćwierci XIII wieku, odkrytymi w północno-wschodniej części III wirydarza (oprac. D. Niemiec)

Fig. 14. Krakow, Dominican monastery. Plan with the remains of kiln No. 2 from the third quarter of the $13^{\text {th }}$ century, discovered in the north-eastern part of the cloister garth III (edited by D. Niemiec)

najstarszego wschodniego skrzydła klasztoru Dominikanów, nieco na północ od jego skraju (Filipowicz 2002, s. 295-298, ryc. 1, 2; Szyma 2004, s. 56-60, ryc. 124, 125; Bojęś-Białasik 2015, s. 34, ryc. 2).

W wyniku badań archeologicznych rozpoczętych w 1938 roku na terenie kościoła i klasztoru Dominikanów w Krakowie i wznowionych na dużą skalę w 2009 roku pozyskano znaczącą liczbę - ponad 700 egzemplarzy - najbardziej oryginalnej grupy ceramiki budowlanej, jaką są późnoromańskie płytki posadzkowe wykonane w technice reliefowej i reliefowo-inkrustowanej. Pod względem artystycznym wyroby te można zaliczyć do najciekawszych przykładów tego rodzaju rzemiosła artystycznego w Krakowie i w Polsce. W ocenie rangi zbioru dominikańskiego uwzględnić należy bogactwo i różnorodność zastosowanych motywów zdobniczych, zarówno roślinnych i figuralnych, a przede wszystkich wysoką jakość odwzorowania tych motywów w płytkach, odciśniętych 


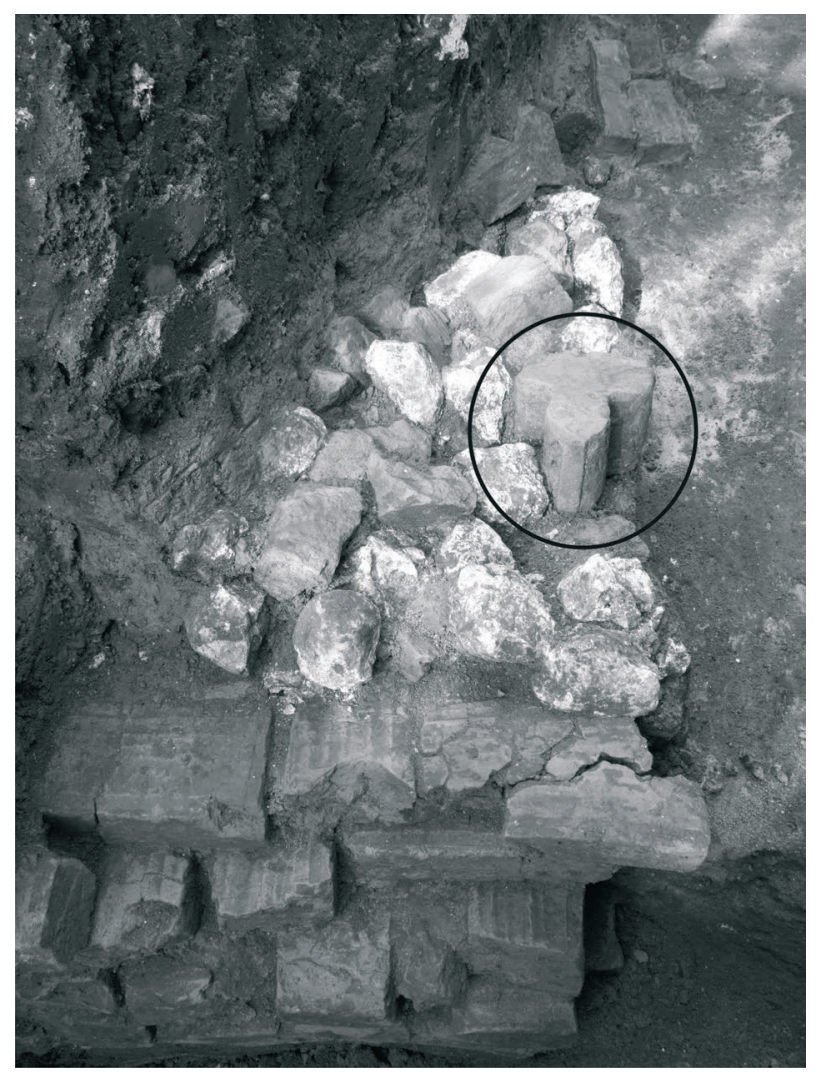

Ryc. 15. Kraków, klasztor Dominikanów. Relikty pieca produkcyjnego nr 2 z 3. ćwierci XIII wieku z wczesnogotycką kształtką o profilu gruszkowatym (zaznaczona otokiem), odkryte w północno-wschodniej części III wirydarza (fot. D. Niemiec)

Fig. 15. Krakow, Dominican monastery. Remains of kiln No. 2 from the third quarter of the $13^{\text {th }}$ century with an early Gothic shaped brick pear-shaped in cross-section (marked with a rim), discovered in the north-eastern part of the cloister garth III (photo by D. Niemiec)

z niezachowanych matryc drewnianych lub glinianych. Wspomniane płytki cechuje też duża różnorodność pod względem technik artystycznych zastosowanych w ich produkcji, zwłaszcza dotyczy to bardzo rzadkiej na ziemiach polskich tzw. techniki reliefowo-inkrustowanej, poświadczonej poza Krakowem (Buczkowski 1939; Żaki 1963, s. 599, 601, ryc. 17, 18; 1965a, s. 283, ryc. 6; 1965b, ryc. 75, 76; Piątkiewicz-Dereniowa 1971; Szewczyk-Wojtasiewicz 1999; 2006b; Głowa 2014; Niemiec 2016, s. 226, ryc. 31, 33-36, 42-43), tylko na nielicznych stanowiskach małopolskich; na przykład pochodzą one z dominikańskiego kościoła św. Jakuba w Sandomierzu (Gołubiew 1975, s. 37, 190-191, nr 41, 42), katedry w Kielcach 

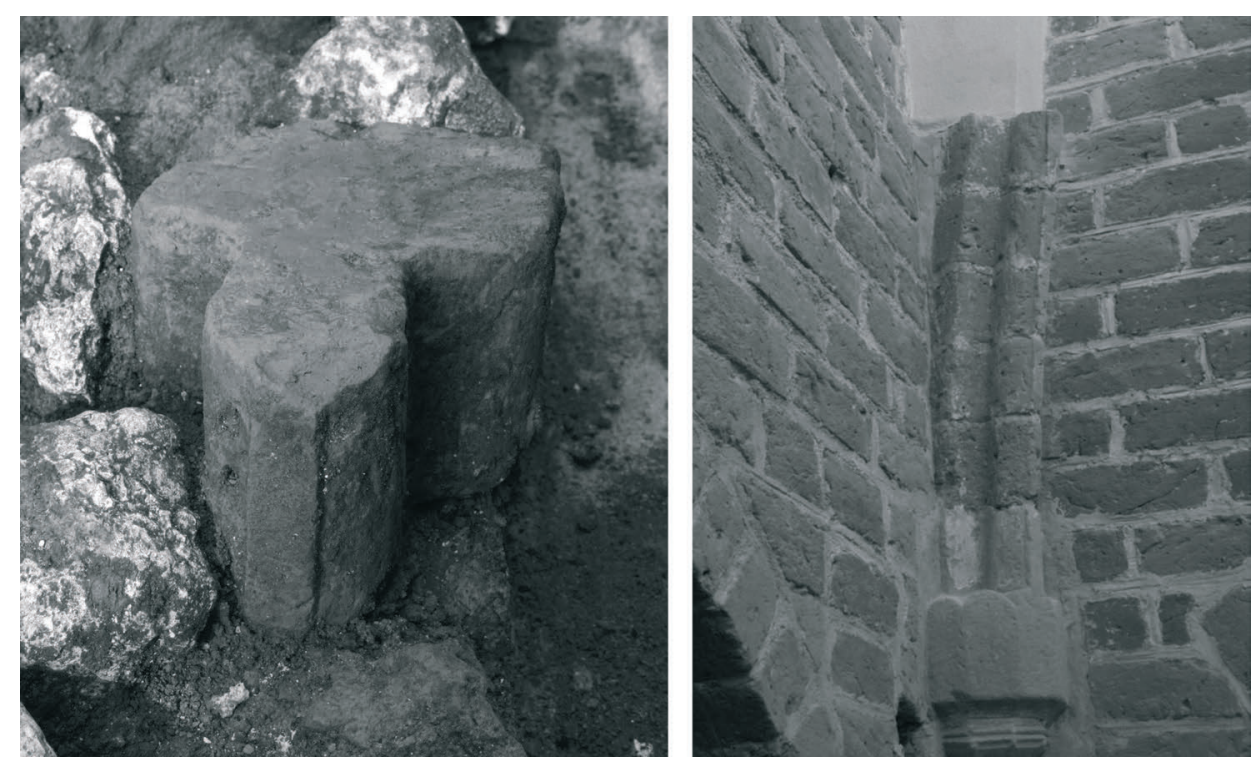

Ryc. 16. Kraków, klasztor Dominikanów. A - wczesnogotycka kształtka o profilu gruszkowatym z 3. ćwierci XIII wieku, stanowiąca element konstrukcyjny żebra sklepiennego, odkryta w kontekście pieca produkcyjnego nr 2 na III wirydarzu; B - wspornik z analogicznym przekrojem żebra sklepiennego zachowany in situ w tzw. Skarbczyku we wschodnim skrzydle klasztoru (fot. D. Niemiec)

Fig. 16. Krakow, Dominican monastery. A - early Gothic shaped brick pear-shaped in cross-section from the third quarter of the $13^{\text {th }}$ century, constituting the construction element of the vault rib, discovered in the context of kiln No. 2 in othe cloister garth III; B - corbel with analogous cross-section of vault rib preserved in situ in the so-called Small Treasury in the eastern wing of the monastery (photo by D. Niemiec)

(Kuczyński 1963, s. 80) i kościoła Benedyktynek w Staniątkach ${ }^{13}$. Warto też podkreślić, że ornamentowane, późnoromańskie płytki posadzkowe odkrywane w Krakowie, w tym na terenie kompleksu dominikańskiego, to grupa znalezisk, która może być datowana w stosunkowo wąskich ramach od połowy XIII po 3. ćwierć XIII wieku. W klasztorze Dominikanów płytki te można bezpośrednio powiązać z odkrytymi niedawno piecami i warstwami budowlanymi, datowanymi po pierwszym najeździe mongolskim z 1241 roku, czyli najwcześniej ze wszystkich znalezisk krakowskich. W całej dotychczasowej literaturze za najstarszą tego rodzaju krakowską posadzkę w Krakowie uważano pavimentum, odkryte w katedrze wawelskiej, ułożone - jak wynika to z zapiski odnotowanej w roczniku kapitulnym krakowskim - na polecenie biskupa Prandoty w 1250 roku, co bez

${ }^{13}$ Uprzejma informacja Pana mgr. Stanisława Cechosza, krakowskiego badacza architektury, o nowych i niepublikowanych odkryciach takich płytek, wtórnie zestawionych w posadzce kościoła Benedyktynek w Staniątkach. 
wątpienia stanowiło część prac związanych z przygotowaniami uroczystości kanonizacyjnych św. Stanisława w latach 1253-1254 (Szewczyk-Wojtasiewicz 1999; 2006b; Niemiec 2016, s. 203-204).

W kontekście rozważań nad pochodzeniem wyspecjalizowanego warsztatu ceramicznego, który rozpoczął swoją działalność w Krakowie po 1241 roku, warto zwrócić uwagę, że dla rzadkich i najbardziej wysublimowanych przedstawień zoomorficznych na płytkach wykonanych w technice reliefowo-inkrustowanej (z wyobrażeniem jelenia), znanych ze znalezisk krakowskich, a konkretnie z klasztoru Dominikanów (Piątkiewicz-Dereniowa 1991, s. 21, nr 1, ryc. 1; Nowak, Turdza 2012, s. 370-371, 374-375, nr 133b.6; Niemiec 2016, s. 230, ryc. 43) i Rynku Głównego (być może zniszczona posadzka kościoła Mariackiego lub św. Wojciecha - por. Głowa 2014, ryc. 2, 6), można wskazać ścisłe odpowiedniki przede wszystkim w wyrobach warsztatów działających na terenie Francji przy czołowych fundacjach królewskich czy biskupich (np. katedry w Laon i Senlis, królewskie pałace w Luwrze i Vincennes, paryskie opactwa Saint-Victor, Saint-Germain-des-Prés, Saint-Martin-des-Champs oraz opactwa Saint Denis i Royaumont pod Paryżem, a także opactwa i budowle świeckie w Reims, koronacyjnym mieście władców Francji), a także warsztatów wywodzących się z Francji i działających na terenie Flandrii i Niderlandów oraz Fryzji (np. Ypres, Utrecht, Dokkum i Longerhouw) (Niemiec 2016, s. 230-231, 238-239 - tam obszerna literatura z analogiami). W Utrechcie płytki analogiczne do krakowskich odkryto również w klasztorze Dominikanów, co pozwala przypuszczać, że ewentualnym, wspólnym źródłem znalezisk holenderskich i krakowskich mogą być warsztaty, które działały przy klasztorach dominikańskich na terenie Francji (Volti 2003, s. 77-79), nie wykluczając najważniejszego warsztatu, który obsługiwał paryski konwent św. Jakuba.

W podsumowaniu należy stwierdzić, że na obecnym etapie badań największe podobieństwa stylistyczne i technologiczne do późnoromańskich płytek krakowskich wykazują zachowane in situ posadzki i pojedyncze płytki z terenu północnej Francji, z szeregu obiektów znajdujących się pomiędzy Bretanią a Flandrią i Pikardią oraz Lotaryngią, a także analogiczne odkrycia z obszaru Fryzji i Niderlandów (Niemiec 2016, s. 230-231, 238-239).

\section{Literatura}

Arszyński M.

2016 Organizacja i technika średniowiecznego budownictwa ceglanego w Prusach w kontekście europejskim, Malbork.

Attila J.

2011 Téglaégetô kemencék a középkori Magyarország területén, A nyíregyházi Jósa András Múzeum Évkönve, t. 53, s. 131-160. 
Betts I. M.

2002 Medieval „Westminster” floor tiles, London.

Bojęś-Białasik A.

2015 The role of architectural research in the preservation of cultural heritage based on the conservation of the atrium - gothic hall of the Dominican priory in Krakow/Rola badań architektonicznych w ochronie dziedzictwa kulturowego na przykładzie konserwacji atrium - sieni gotyckiej klasztoru Dominikanów w Krakowie, Czasopismo Techniczne, Architektura, z. 6-A (9), s. 25-40.

Bojęś-Białasik A., Niemiec D.

2013 Kościót i klasztor dominikanów w Krakowie w świetle badań archeologiczno-architektonicznych w latach 2010-2012, [w:] Sztuka w kręgu krakowskich dominikanów, red. A. Markiewicz, M. Szyma, M. Walczak, Kraków, s. 257-313.

2016a Klasztorne fundacje biskupa Iwona Odrowqż̇a w świetle wyników badań archeologiczno-architektonicznych klasztoru dominikanów w Krakowie i opactwa cystersów w Mogile, [w:] Działalność fundacyjna biskupów krakowskich, t. 1, red. M. Walczak, s. 239-278.

2016b Medieval ceramics techniques in architecture of cracow's Dominicans, Forum Urbes Medii Aevi 13, s. 35-48.

2016c Opactwa w Lubiażu, Trzebnicy i Mogile a poczatki cysterskiej architektury ceglanej na Ślqsku i w Małopolsce w kontekście filiacyjnych zależności warsztatowych, [w:] Architektura sakralna w poczqtkach państwa polskiego (X-XIII w.), red. T. Janiak, D. Stryniak, Gniezno, s. 459-506.

Brunetti V., Carlo A. M. di, Basso A. P.

1987 Le strutture murarie, [w:] Archeologia medievale a Bologna. Gli scavi nel Convento di San Domenico. Catalogo, Bologna, Museo civico archeologico, 4 aprile-31 maggio 1987, red. S. Gelichi, R. Merlo, Bologna, s. 225-228.

Buczkowski K.

1939 Płytki posadzki z XIII w. w kościele oo. Dominikanów Krakowie, Biuletyn Historii Sztuki i Kultury, R. 7, nr 2, s. 197-200.

Dębowski T.

1997a Kraków - klasztor dominikanów. Wyniki nadzoru archeologicznego prac ziemnych, t. I. Opis i dokumentacja rysunkowa wykopów, maszynopis w archiwum Wojewódzkiego Urzędu Ochrony Zabytków w Krakowie, Kraków.

1997b Kraków - klasztor dominikanów. Wyniki nadzoru archeologicznego prac ziemnych, t. II. Inwentarz zabytków ruchomych, maszynopis w archiwum Wojewódzkiego Urzędu Ochrony Zabytków w Krakowie, Kraków.

Drda M.

1983 Cihelna z 13. století v Milevsku, Archaeologia historica, t. 8, s. 167-173.

Eames E. S.

1961 Athirteenth-century tile kiln site at North Grange, Meaux, Beverley, Yorkshire, Medieval Archaeology, t. 5, s. 137-168. 
Filipowicz M.

2002 Sprawozdanie z badań architektonicznych budynku dawnej biblioteki klasztornej, [w:] Dominikanie w środkowej Europie w XIII-XV wieku: aktywność duszpasterska i kultura intelektualna, red. J. Kłoczowski, J. A. Spież, Poznań,

Florek M. s. 293-300.

1993 Wyniki badań archeologicznych prowadzonych przy kościele p.w. św. Jakuba i dawnym klasztorze dominikanów w Sandomierzu w latach 1990-1992, Materiały i Sprawozdania Rzeszowskiego Ośrodka Archeologicznego za lata 1991-1992, s. 111-138.

1994 Kościól św. Jakuba i dawny klasztor dominikanów w Sandomierzu. Wyniki badań archeologiczno-architektonicznych, Kwartalnik Historii Kultury Materialnej, R. 42, nr 1, s. 3-25.

Frazik J. T.

1978 Sklepienia żebrowe w Polsce w XV w., [w:] Sztuka i ideologia XV wieku, red. P. Skubiszewski, Warszawa, s. 521-566.

Frycz J.

1978 Architektura zamków krzyżackich, [w:] Sztuka pobrzeża Bałtyku, red. H. Fruba, Warszawa 1978, s. 19-48.

Głowa W.

2014 Średniowieczne „kachle” krakowskie. Wybrane zagadnienia technologiczne, [w:] Rzeczy i ludzie. Kultura materialna w późnym średniowieczu i w okresie nowożytnym. Studia dedykowane Marii Dabrowskiej, red. M. Bis, W. Bis, Warszawa, s. 91-104.

Gołubiew Z.

1975 Kościót podominikański p.w. św. Jakuba w Sandomierzu w XIII stuleciu i jego dekoracja architektoniczna, [w:] Studia nad historiq dominikanów w Polsce 1222-1972, t. 2, red. J. Kłoczowski, Warszawa, s. 9-169.

Haton G.

2009 Medieval floor tiles in Kilsby Church: evidence of a rare medieval tiled church floor, The Kilsby Kronicle, nr 69, s. 1-3.

Kopera F.

1926 Średniowieczna architektura kościoła i klasztoru OO Dominikanów w Krakowie. Na podstawie zdjęć architektonicznych Zygmunta Hendla, Rocznik Krakowski, t. 20, s. 57-76.

Kuczyński J.

1963 Sprawozdanie z badań katedry kieleckiej za rok 1961, Rocznik Muzeum

Świętokrzyskiego, t. 1, s. 67-89.

Landgraf E.

1993 Ornamentierte Bodenfliesen des Mittelalters in Süd- und Westdeutschland 1150-1550, t. 1-3, Stuttgart.

Lemmen van $\mathrm{H}$.

2010 Medieval tiles, Oxford. 
Lenkiewicz T.

1959 Kościót Marii Magdaleny w Krakowie w świetle ostatnich odkryć archeologicznych, Biuletyn Krakowski, t. 1, s. 78-98.

Łyczak M., Górski R.

2012 Ratownicze badania wykopaliskowe w rejonie bazyliki Św. Trójcy na terenie południowej części placu Dominikańskiego w Krakowie, Krzysztofory. Zeszyty Naukowe Muzeum Historycznego Miasta Krakowa, nr 30, s. 235-242.

2013 Wyniki badań archeologicznych prowadzonych w rejonie bazyliki św. Trójcy na terenie placu Dominikańskiego w Krakowie, [w:] Sztuka w kręgu krakowskich dominikanów, red. A. Markiewicz, M. Szyma, M. Walczak, Kraków, s. 235-256.

Niemiec D.

2016 Ornamentowane posadzki w kościołach romańskich na ziemiach polskich, [w:] Architektura sakralna w poczqtkach państwa polskiego (X-XIII w.), red. T. Janiak, D. Stryniak, Gniezno, s. 191-254.

Norton Ch.

1992 Carreaux de pavement du Moyen-Age et de la Renaissance, Paris.

Nowak J. T., Turdza W.

2012 Skarby krakowskich klasztorów, t. 2, Kraków.

Oosten van R.

2012 Het vertrek van de veertiende-eeuwse pottenbakkers uit de Bemuurde Weerd: verplicht of vrijwillig? Een herinterpretatie van de historische en archeologische gegevens, Oud Utrecht Jaarboek 2012, s. 133-150.

Piątkiewicz-Dereniowa M.

1971 Plytki posadzkowe z opactwa benedyktynów w Tyńcu, Folia Historiae Atrium, t. 6-7, s. 239-263.

1991 Artystyczna ceramika europejska w zbiorach polskich, Warszawa.

Rajman J.

2012 Krakowska civitas soltysów Piotra i Salomona, [w:] Społeczeństwo Polski średniowiecznej, t. 12, Warszawa, s. 47-68.

Rojkowska H.

2014 Odkrycia przed kościołem Dominikanów w Krakowie, [w:] Kraków romański, red. J. M. Małecki, Kraków, s. 105-120.

Rooyen van C.

2008 Vloer in de maak: de productie van plavuizen in de late middeleeuwen, [w:] Over de vloer. Met voeten getreden erfgoed, red. E. Koldeweij, Amersfoort, s. 64-77.

Szewczyk-Wojtasiewicz M.

1999 Ceramiczne płytki posadzkowe z katedry romańskiej na Wawelu, Slavia Antiqua, t. 50, s. 151-167.

2006a Ceramiczna płytka posadzkowa, [w:] Kraków w chrześcijańskiej Europie XXIII w. Katalog wystawy, red. E. Firlet, E. Zaitz, Kraków, s. 388-389, nota nr 9.

2006b Późnoromańska posadzka ceramiczna w katedrze na Wawelu, Acta Archaeologica Waweliana, t. 3, s. 85-106. 
Szyma M.

2004 Kościót i klasztor dominikanów w Krakowie. Architektura zespołu klasztornego do lat dwudziestych XIV wieku, Kraków.

Tonezzer L.

2002 Mittelalterliche Ziegelbrennöfens, [w:] Mittelalterliche Öfen und Feuerungsanlagen. Beiträge des 3. Kolloquiums des Arbeitskreises zur archäologischen Erforschung des mittelalterlichen Handwerks, red. R. Röber, Materialhefte zur Archäologie in Baden-Württemberg 62, Stuttgart, s. 101-114.

Volti P.

2003 Les couvents des ordres mendiants et leur environnement à la fin du Moyen Âge. Le nord de la France et les anciens Pays-Bas méridionaux, Paris.

Żaki A.

1963 Archäologische Forschungen über frühmittelalterliche Krakau, Arbeitsund Forschungsberichte zur sächsischen Bodendenkmalpflege, t. 11/12, s. 581-601.

1965a Badania nad przedlokacyjnym Krakowem w 1962 roku (seria X), Sprawozdanie Archeologiczne, t. 17, s. 278-287.

1965b Poczatki Krakowa, Kraków.

\section{KILNS FOR FIRING CONSTRUCTION CERAMICS AND LIMEKILNS IN THE $13^{\text {TH }}$ CENTURY DOMINICAN MONASTERY IN CRACOW}

Summary

The article presents the relics of $13^{\text {th }}$-century kilns, discovered in the area of Krakow Dominican monastery, used to produce bricks and other high-quality ceramic products, including shaped bricks and late Romanesque floor tiles, as well as for limestones calcination. Other aspects of the $13^{\text {th }}$-century construction workshop and facilities recorded in this place during archaeological excavations were also presented. The discovered in the monastery late Romanesque and early Gothic brick architectural details, including decorated floor tiles, both finished products and semi-finished products were characterized.

The origins of this production can be attributed to the 1230s, when brick as a new building material first appeared in the architecture of the Dominican monastery in Krakow. Morphological and technological features of bricks coming from the oldest parts of this structure $(7.5-8 \times 11-12.5 \times 25-27 \mathrm{~cm})$ as well as from the Dominican monastery in Sandomierz $(7.0-8.5 \times 12.0-13.5 \times 26-27 \mathrm{~cm})$ indicate the Italian provenance of the Lesser Poland's workshop producing construction ceramics. A similar material was used for the construction of the dormitory and refectory of the Dominican monastery in Bologna from the first half of the $13^{\text {th }}$ century $(7.0-8.5 \times 11-13.5 \times 27-29.5 \mathrm{~cm})$. In Italian literature it is emphasized that the size, and especially the height of the bricks made in the Bologna monastery, differed considerably from the typical products produced by the city brickworks in Bologna $(5 \times 12.6 \times 28.5 \mathrm{~cm})$.

In turn, in the context of considerations on the origins of another specialized construction ceramics workshop, which began its activity at the Krakow Dominican monastery after 1241 , it is worth noting that the most refined zoomorphic representations on tiles made 
in the relief-inlay technique have their counterparts primarily in products of workshops operating in France at the leading royal or bishop's foundations as well as amongst the workshops originating from France and operating in Flanders, the Netherlands and Frisia. 
